\title{
Copper(II) complexes of $N$-propargyl cyclam ligands reveal a range of coordination modes and colours, and unexpected reactivity
}

Andrew J. Counsell, ${ }^{1}$ Mingfeng Yu, ${ }^{2}$ Mengying Shi, ${ }^{1}$ Angus T. Jones, ${ }^{1}$ James M. Batten, ${ }^{1}$ Peter Turner, ${ }^{1}$ Matthew H. Todd ${ }^{3 *}$ and Peter J. Rutledge ${ }^{1 *}$

1. School of Chemistry, The University of Sydney, Sydney, New South Wales 2006, Australia

2. Drug Discovery and Development, Cancer Research Institute, Clinical and Health Sciences, University of South Australia, Adelaide, South Australia 5001, Australia

3. School of Pharmacy, University College London, 29-39 Brunswick Square, London WC1N $1 \mathrm{AX}, \mathrm{UK}$

* Corresponding authors: Professor Peter J. Rutledge, peter.rutledge@sydney.edu.au, +61 2 93515020 and Professor Matthew H. Todd, matthew.todd@ucl.ac.uk, +44 2077535568

\begin{abstract}
The coordination chemistry of $N$-functionalised cyclam ligands has a rich history, yet cyclam derivatives with pendant alkynes are largely unexplored. This is despite the significant potential and burgeoning application of $N$-propargyl cyclams and related compounds in the creation of diversely functionalised cyclam derivatives via copper-catalysed azide-alkyne 'click' reactions. Herein we describe single crystal X-ray diffraction and spectroscopic investigations of the coordination chemistry of copper(II) complexes of cyclam derivatives with between 1 and 4 pendant alkynes. The crystal structures of these copper complexes unexpectedly reveal a range of coordination modes, and the surprising occurrence of five unique complexes within a single recrystallisation of the tetra- $N$-propargyl cyclam ligand. One of these species exhibits weak intramolecular copper-alkyne coordination, and another is formed by a surprising intramolecular copper-mediated hydroalkoxylation reaction with the solvent methanol, transforming one of the pendant alkynes to an enol ether. Multiple functionalisation of the tetra- $N$-propargyl ligand is demonstrated via a 'tetra-click' reaction with benzyl azide, and the copper-binding behaviour of the resulting tetra-triazole ligand is characterised spectroscopically.
\end{abstract}




\section{KEYWORDS}

cyclam; azamacrocycle ligands; alkyne complexes; crystallography; hydroalkoxylation

\section{INTRODUCTION}

Cyclam 1 (Figure 1) and functionalised cyclam derivatives have a long and distinguished history as macrocyclic ligands that give rise to metal complexes with diverse and interesting properties, and the coordination modes, reactivity and bioactivity of metal complexes of $\mathrm{N}$ functionalised cyclam ligands continue to draw sustained research interest. ${ }^{1-4}$

Functionalisation of one or more of the secondary amines in the azamacrocycle is easily achieved, affording diverse and significant changes to the properties of the resulting ligand and metal complexes. How ligand and complex properties vary depends primarily upon the degree of amine substitution, the electronic and steric properties of $N$-substituents, the metal cation, the nature of anionic species present during complexation, and $\mathrm{pH}^{3}$ The resultant versatility has enabled the application of cyclam derivatives across a wide range of areas including chemosensing, ${ }^{5,6}$ biomimicry, ${ }^{7,8}$ molecular switches, ${ }^{9,}{ }^{10}$ supramolecular systems, ${ }^{11}$, 12 catalysis, ${ }^{13-15}$ and medicine. ${ }^{16-18}$

Pendant groups including amine, alcohol, thiol, ester, carboxylic acid, amide, carbamate, urea, sulfonamide, nitrile, thioester, pyridyl, triazolyl and phosphonate functionality have been incorporated on side-arms of varying length and complexity, ${ }^{2,3}$ to modulate properties such as chelate effects, the selectivity of metal ion-binding, side-chain reactivity, and pendant lability. From the simple aminoethyl derivative 2 used to study the pH-dependence of side-chain coordination to a chelated nickel ion, ${ }^{19}$ this field has expanded to include compounds such as the dansylate 3 cast as the basis for a light-emitting molecular machine, ${ }^{10}$ the likes of naphthalimide derivative 4 which incorporate fluorescent dyes for metal ion sensing, ${ }^{20-22}$ and molecules of general structure 5, which have demonstrated potency against drug-resistant Mycobacterium tuberculosis (Figure 1). ${ }^{23,24}$ Relatively little attention has been paid to cyclam derivatives bearing alkyne pendant groups, and the metal complexes they form. The recently reported surface modification of glassy carbon electrodes for $\mathrm{CO}_{2}$ reduction with a series of $\left[\mathrm{Ni}(\text { alkynyl-cyclam) }]^{2+}\right.$ complexes, serves as an isolated example. ${ }^{25}$ We have ongoing interests in $N$-propargyl cyclams as precursors for $\mathrm{Cu}(\mathrm{I})$-catalysed azide-alkyne Huisgen 'click' reactions, which enable the introduction of more complex pendant functionality as in $\mathbf{4}$ and $\mathbf{5}$ 
above, ${ }^{26-28}$ a strategy that has also been employed in a number of other metal chelating systems. $^{29}$

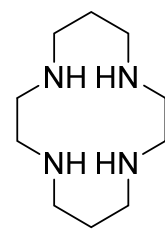

1

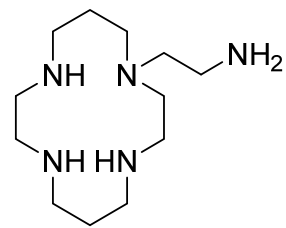

2<smiles>CN(C)c1cccc2c(S(=O)(=O)NCCN3CCCNCCNCCCNCC3)cccc12</smiles><smiles></smiles>

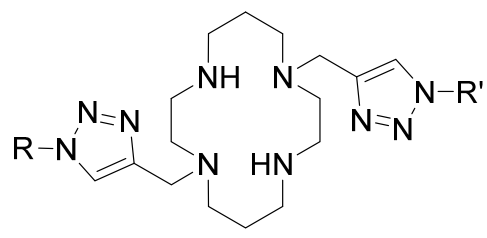

Figure 1. Cyclam 1 and derivatives 2-5 with pendant ligands that have a broad range of applications.

Herein we report the structural characterisation of the copper complexes of $N$-propargyl cyclams 6-9 bearing 1-4 pendant alkynes (Figure 2). This group of ligands was chosen to probe the effect that the degree of amine substitution, and the electronic and steric properties of $N$-substituents, have upon the structure of their $\mathrm{Cu}(\mathrm{II})$ complexes. The complexes exhibit an interesting variety of alkyne coordination modes and stereochemistry across the series and individually. Structures of the $\mathrm{Cu}(\mathrm{II})$ complexes of 6-9 are reported, including a series of isomers of the $\mathrm{Cu}(9)$ complex all obtained from a single recrystallisation, and an unexpected enol ether complex derived from the reaction of 9 with methanol solvent. 


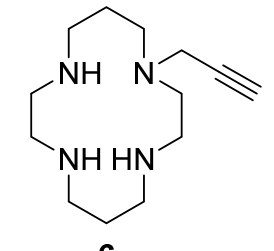

6

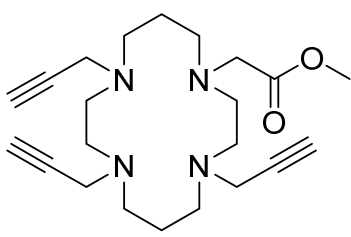

8<smiles>C#CCN1CCCN(C)CCCN(CC#C)CCC1</smiles>

7

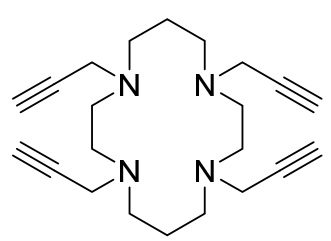

9

Figure 2. Functionalised cyclam ligands 6-9 bearing pendant alkynes.

\section{RESULTS AND DISCUSSION}

Synthesis of Ligands and Metal Complexes

Preparation of the mono $N$-propargyl cyclam 6 proceeded in good overall yield (68\%) from cyclam 1 over three steps (Scheme 1 and Scheme S1, Supporting Information (SI)): tri-Boc protection, alkylation with propargyl bromide, and deprotection under acidic conditions. The bis-alkyne derivative 7 was obtained through conversion of cyclam 1 to a bis-aminal-bridged intermediate (Scheme S1, SI), which was alkylated and deprotected with basic work-up, then methylated with an Eschweiler-Clarke reaction to form 7, in good overall yield (62\%).

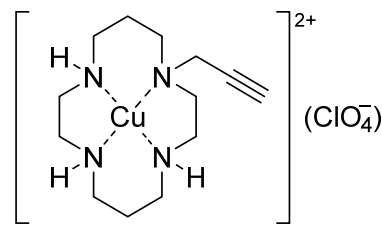

$[\mathrm{Cu}(6)]\left(\mathrm{ClO}_{4}\right)_{2}$<smiles>CC#CCN1CCCN(C)C12CC1CN(CC)CCCN12</smiles>

$[\mathrm{Cu}(7)]\left(\mathrm{ClO}_{4}\right)_{2}$

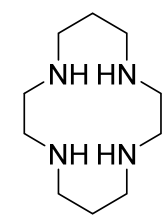

1
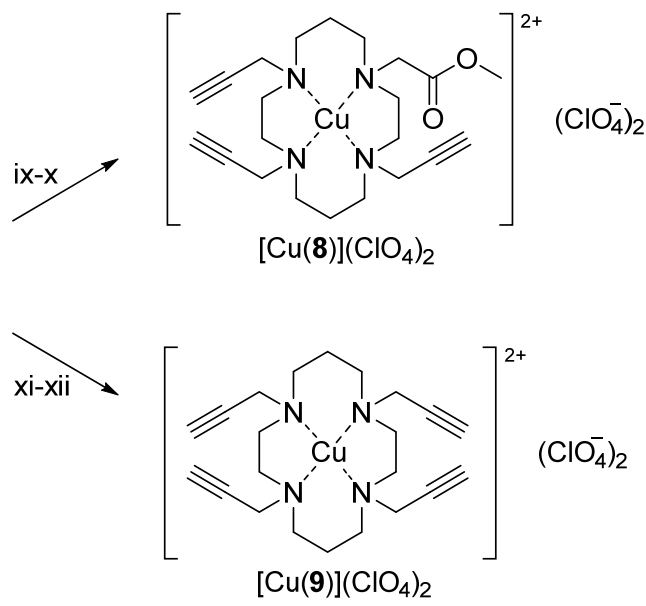

$\left(\mathrm{ClO}_{4}^{-}\right)_{2}$

Scheme 1. Synthesis of ligands 6-9 and their copper complexes. Reagents and conditions: (i) (Boc) $)_{2} \mathrm{O}, \mathrm{Et}_{3} \mathrm{~N}$, $\mathrm{CH}_{2} \mathrm{Cl}_{2},-15{ }^{\circ} \mathrm{C}$ to rt, $16 \mathrm{~h}, 77 \%$; (ii) $\mathrm{BrCH}_{2} \mathrm{C} \equiv \mathrm{CH}, \mathrm{Na}_{2} \mathrm{CO}_{3}, \mathrm{rt}, 16 \mathrm{~h}, 95 \%$; (iii) TFA/ $\mathrm{CH}_{2} \mathrm{Cl}_{2}$ (1:5), rt, $72 \mathrm{~h}, 93 \%$; (iv) $\mathrm{Cu}\left(\mathrm{ClO}_{4}\right)_{2} \cdot 6 \mathrm{H}_{2} \mathrm{O}$, EtOH, reflux, $1 \mathrm{~h}, 80 \%$; (v) $\mathrm{CH}_{2} \mathrm{O}, \mathrm{H}_{2} \mathrm{O}, \mathrm{rt}, 16 \mathrm{~h}, 76 \%$; (vi) $\mathrm{BrCH}_{2} \mathrm{C} \equiv \mathrm{CH}_{2} \mathrm{CH}_{3} \mathrm{CN}, \mathrm{rt}, 16$ 
h, 90\%; (vii) $\mathrm{CH}_{2} \mathrm{O}, \mathrm{HCO}_{2} \mathrm{H}, \mathrm{H}_{2} \mathrm{O}$, reflux, $24 \mathrm{~h}, 90 \%$; (viii) $\mathrm{Cu}\left(\mathrm{ClO}_{4}\right)_{2} \cdot 6 \mathrm{H}_{2} \mathrm{O}$, EtOH, reflux, $1 \mathrm{~h}, 81 \%$; (ix) $\mathrm{BrCH}_{2} \mathrm{C} \equiv \mathrm{CH}$ (3.0 eq), $\mathrm{BrCH}_{2} \mathrm{CO}_{2} \mathrm{CH}_{3}(1.0 \mathrm{eq}), \mathrm{Na}_{2} \mathrm{CO}_{3}, \mathrm{CH}_{3} \mathrm{CN}$, reflux, $16 \mathrm{~h}, 10 \% ;(\mathrm{x}) \mathrm{Cu}\left(\mathrm{ClO}_{4}\right)_{2} \cdot 6 \mathrm{H}_{2} \mathrm{O}, \mathrm{EtOH}$, reflux, 1 h, 77\%; (xi) $\mathrm{BrCH}_{2} \mathrm{C} \equiv \mathrm{CH}, \mathrm{H}_{2} \mathrm{O}: \mathrm{CH}_{3} \mathrm{CN}$ (1:1), $\mathrm{NaOH}$, rt, 16 h, 72\%; (xii) $\mathrm{Cu}\left(\mathrm{ClO}_{4}\right)_{2} \cdot 6 \mathrm{H}_{2} \mathrm{O}$, EtOH, reflux, $1 \mathrm{~h}, 80 \%$.

Initial attempts to synthesise $\mathbf{8}$ via alkylation of tri-Boc cyclam with methyl bromoacetate failed at the deprotection stage. Once the tri-Boc/ ester intermediate $\mathbf{1 0}$ is unmasked and exposed to the basic conditions used in the reaction with propargyl bromide, mono $N$-alkylated cyclam 11 is prone to an intramolecular cyclisation reaction which would form bicyclic lactam 12 (Scheme 2), as reported previously for the ethyl ester analogue of $11 .{ }^{30}$ Ligand 8 was instead obtained directly from cyclam 1 via a one-pot synthesis with the slow, sequential addition of propargyl bromide and methyl bromoacetate in strict 3:1 stoichiometry under basic conditions (Scheme 1) in a poor but tolerable yield (10\%). The tetrapropargyl ligand 9 was prepared in good yield (72\%) using the direct, one-step tetra- $N$-alkylation reaction we have recently reported, with propargyl bromide and a base in a 'miscible biphasic' system. ${ }^{31}$

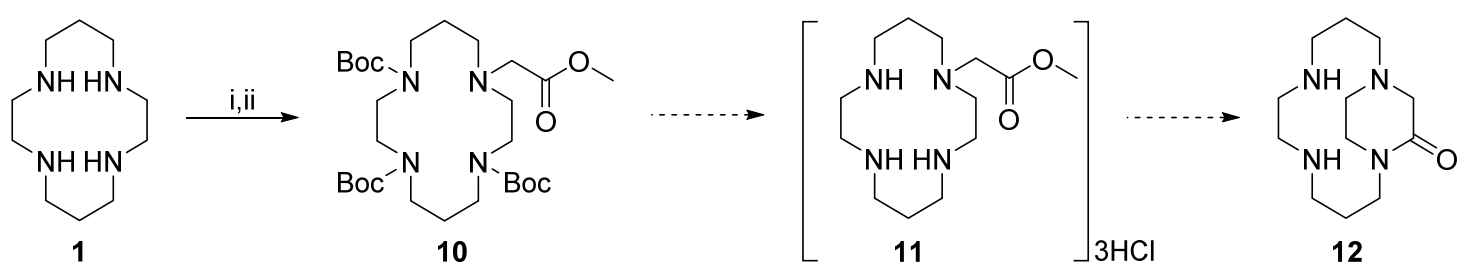

Scheme 2. Attempted synthesis of $\mathbf{8}$ via $\mathbf{1 0}$ was unsuccessful as the mono- $N$-alkyl cyclam $\mathbf{1 1}$ cyclises to the bicyclic lactam 12 in alkaline solution. Reagents and conditions: (i) (Boc) ${ }_{2} \mathrm{O}, \mathrm{Et}_{3} \mathrm{~N}, \mathrm{CH}_{2} \mathrm{Cl}_{2},-15^{\circ} \mathrm{C}$ to rt, $16 \mathrm{~h}$, $77 \%$; (ii) $\mathrm{BrCH}_{2} \mathrm{CO}_{2} \mathrm{CH}_{3}, \mathrm{Na}_{2} \mathrm{CO}_{3}, \mathrm{rt}, 16 \mathrm{~h}, 95 \%$; then deprotection with $2 \mathrm{M} \mathrm{HCl}$ in 1,4-dioxane, rt, and attempted alkylation with $\mathrm{BrCH}_{2} \mathrm{C} \equiv \mathrm{CH}$ and $\mathrm{Na}_{2} \mathrm{CO}_{3}$, rt. Cyclised product 12 was not isolated, but has been reported previously to form under similar conditions, see text for further details.

Metal complexes were prepared by dissolving each of the ligands 6-9 in ethanol with copper(II) perchlorate and heating at reflux for one hour, then cooling on ice to precipitate the complex. This procedure, adapted from one we have previously reported for related systems, ${ }^{23}$, 32 afforded the metal complexes $[\mathrm{Cu}(6)]\left(\mathrm{ClO}_{4}\right)_{2},[\mathrm{Cu}(7)]\left(\mathrm{ClO}_{4}\right)_{2},[\mathrm{Cu}(\mathbf{8})]\left(\mathrm{ClO}_{4}\right)_{2}$, and $[\mathrm{Cu}(9)]\left(\mathrm{ClO}_{4}\right)_{2}$ in high yields $(77-81 \%)$. 


\section{Structural Characterisation of Mono-, Di- and Tri-propargyl Complexes}

Single crystals of $\mathrm{Cu}(\mathrm{II})$ perchlorate complexes of ligands 6,8 and 9 were each obtained through the slow diffusion of an aqueous $\mathrm{Cu}\left(\mathrm{ClO}_{4}\right)_{2}$ phase with a methanolic phase containing the ligand. Attempts to crystallise $[\mathrm{Cu}(7)]\left(\mathrm{ClO}_{4}\right)_{2}$ from methanol were unsuccessful, and this was instead accomplished via the slow evaporation of a solution of the complex in acetonitrile. Structure determination and crystallographic details are provided electronically as part of the SI.

The complex molecule $[\mathrm{Cu}(6)]\left(\mathrm{ClO}_{4}\right)_{2}$ adopts a slightly distorted octahedral geometry, with weak axial perchlorate coordination to the metal centre (Figure 3 and SI Figure SX1, As is the case with $[\mathrm{Cu}(6)]^{2+}$, the single crystal structure of the $[\mathrm{Cu}(7)]^{2+}$ complex dication lacks propargyl substituent coordination to the metal centre (Figure 4 and SI Figure SX2). The presence of acetonitrile, a softer and more effective Lewis base, evidently excludes axial perchlorate coordination and the macrocyclic complex is essentially five coordinate with an apical copper(II) to acetonitrile nitrogen bond length of 2.229(3) $\AA$ (see also Table 1). There appears to be a weak and, presumably, essentially electrostatic interaction between the metal ion and the oxygen of a perchlorate anion trans to the acetonitrile, with the metal ion to oxygen site distance being 3.914(4) $\AA$. The metal coordination environment is distorted squarepyramidal, with a trigonal index $(\tau)$ of 0.34 (where $\tau$ ranges from 0 to 1 , indicating the extent of transition from the ideal square pyramidal to ideal trigonal bipyramidal geometries, respectively). ${ }^{38} \mathrm{The}[\mathrm{Cu}(7)]^{2+}$ complex dication adopts the trans-I configuration. ${ }^{39}$

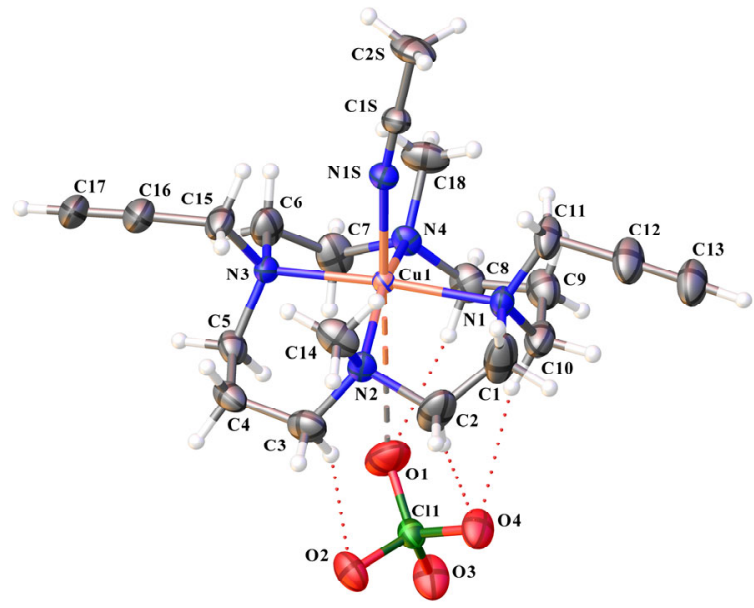

Figure 4. Olex 2 depiction of trans $-I-[\mathrm{Cu}(7)(\mathrm{CH} 3 \mathrm{CN})]^{2+} \cdot 2 \mathrm{ClO} 4-$, with ellipsoids shown at the $50 \%$ probability level. The second perchlorate counterion is not shown. 
and SI Table SX1). The $\mathrm{Cu}-\mathrm{N}$ macrocyclic amine distances vary from 2.008(2) to 2.0802(19) $\AA$, similar to the theoretical expectation of $2.07 \AA .^{33}$ The relatively long metal to oxygen axial bond lengths of 2.517(2) and 2.540(2) $\AA$ reflect the character of perchlorate ion and, presumably, a Jahn-Teller distortion. The angles formed between the macrocycle nitrogen, metal and perchlorato oxygen sites range from $85.37(7)$ to $94.37(7)^{\circ}$ for one perchlorate counterion and $84.77(8)$ to $95.08(7)^{\circ}$ for the second. The perchlorato oxygen to metal to trans perchlorato oxygen angle is $177.50(6)^{\circ}$.

Following chelation of a metal ion, a cyclam complex which exhibits a nominally square planar arrangement of nitrogen donors will adopt one of five configurations according to the spatial orientations of the backbone amine substituents: $R S R S, R R R S, S S R R, R S S R$ and $R R R R$, respectively termed trans-I to trans-V. ${ }^{34}$ The cyclam fragment $[\mathrm{Cu}(\mathbf{6})]^{2+}$ adopts the preferred trans-III configuration, with adjacent $N$-alkyl substituents $\left(\mathrm{R}-\mathrm{N}-\left(\mathrm{CH}_{2}\right)_{3}-\mathrm{N}-\mathrm{R}\right)$ displaced from the $\mathrm{Cu}-\mathrm{N}$ plane. In spite of the tendency for similar complexes to exhibit metal-alkyne coordination, ${ }^{35-37}$ no such interaction is observed here between the $N$-propargyl group (C11C13) and the metal centre.

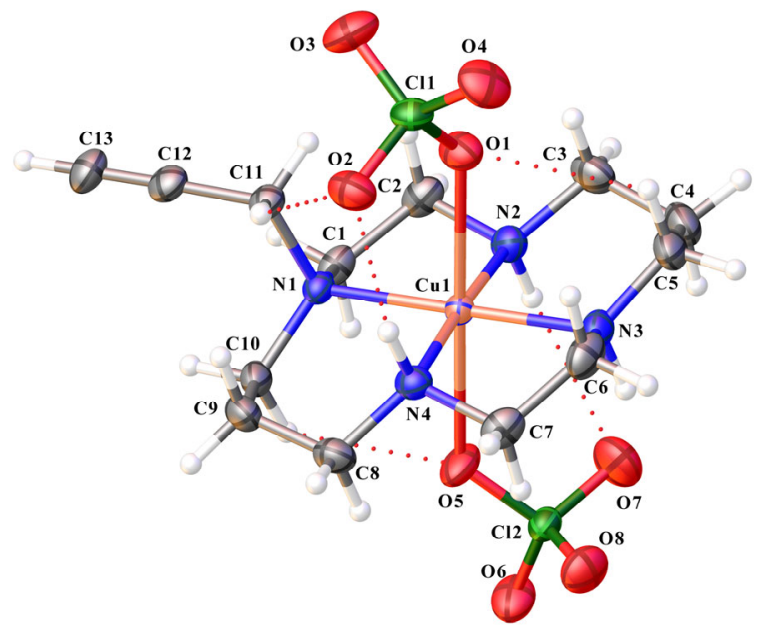

Figure 3. Olex2 depiction of trans-III- $[\mathrm{Cu}(6)]\left(\mathrm{ClO}_{4}\right)_{2} \cdot 0.25 \mathrm{CH}_{3} \mathrm{OH}$, with displacement ellipsoids shown at the $50 \%$ level. A disordered methanol solvate molecule is not shown.

Table 1. Selected bond distances $(\AA)$ within the metal coordination sphere observed in structures of the $N$ propargyl cyclam complexes $[\mathrm{Cu}(6)]\left(\mathrm{ClO}_{4}\right)_{2},[\mathrm{Cu}(7)]\left(\mathrm{ClO}_{4}\right)_{2}$, and $[\mathrm{Cu}(\mathbf{8})]\left(\mathrm{ClO}_{4}\right)_{2}$.

$[\mathrm{Cu}(\mathbf{6})]\left(\mathrm{ClO}_{4}\right)_{2} \quad[\mathrm{Cu}(\mathbf{7})]\left(\mathrm{ClO}_{4}\right)_{2} \quad[\mathrm{Cu}(\mathbf{8})]\left(\mathrm{ClO}_{4}\right)_{2}$




\begin{tabular}{llll}
\hline $\mathrm{Cu}-\mathrm{O} 1^{\mathrm{a}}$ & $2.5170(18)$ & & \\
$\mathrm{Cu}-\mathrm{O} 5^{\mathrm{a}}$ & $2.5403(18)$ & & \\
$\mathrm{Cu}-\mathrm{N} 1$ & $2.0802(19)$ & $2.126(3)$ & $2.1071(19)$ \\
$\mathrm{Cu}-\mathrm{N} 2$ & $2.015(2)$ & $2.074(3)$ & $2.0615(18)$ \\
$\mathrm{Cu}-\mathrm{N} 3$ & $2.0281(19)$ & $2.111(3)$ & $2.0844(18)$ \\
$\mathrm{Cu}-\mathrm{N} 4$ & $2.008(2)$ & $2.081(3)$ & $2.0529(17)$ \\
$\mathrm{Cu}-\mathrm{N} 1 \mathrm{~S}^{\mathrm{b}}$ & & $2.229(3)$ & \\
$\mathrm{Cu}-\mathrm{O} 1^{\mathrm{c}}$ & & & $2.2477(15)$ \\
\hline${ }^{a}$ O of perchlorate; ${ }^{b}$ N of solvent, acetonitrile; $^{c}$ carbonyl O of pendant ester
\end{tabular}

As is the case with $[\mathrm{Cu}(6)]^{2+}$, the single crystal structure of the $[\mathrm{Cu}(7)]^{2+}$ complex dication lacks propargyl substituent coordination to the metal centre (Figure 4 and SI Figure SX2). The presence of acetonitrile, a softer and more effective Lewis base, evidently excludes axial perchlorate coordination and the macrocyclic complex is essentially five coordinate with an apical copper(II) to acetonitrile nitrogen bond length of 2.229(3) $\AA$ (see also Table 1). There appears to be a weak and, presumably, essentially electrostatic interaction between the metal ion and the oxygen of a perchlorate anion trans to the acetonitrile, with the metal ion to oxygen site distance being 3.914(4) $\AA$. The metal coordination environment is distorted squarepyramidal, with a trigonal index $(\tau)$ of 0.34 (where $\tau$ ranges from 0 to 1 , indicating the extent of transition from the ideal square pyramidal to ideal trigonal bipyramidal geometries, respectively). ${ }^{38}$ The $[\mathrm{Cu}(7)]^{2+}$ complex dication adopts the trans-I configuration. ${ }^{39}$

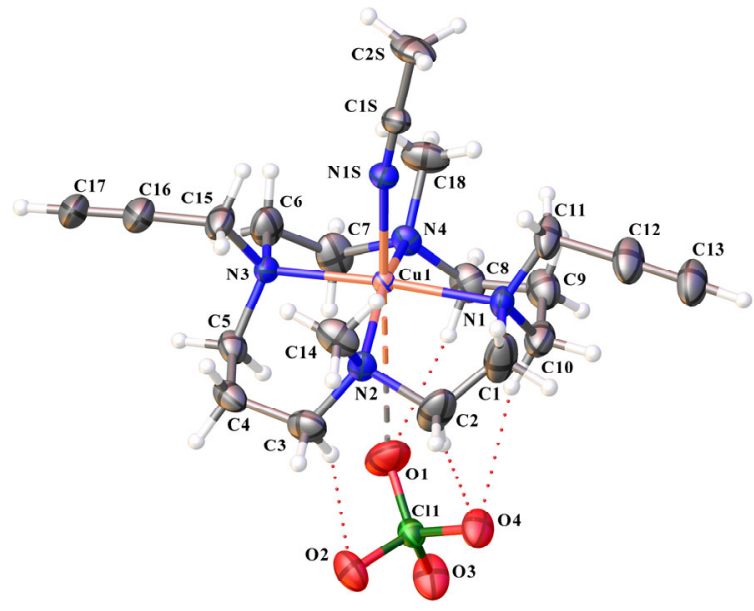

Figure 4. Olex2 depiction of trans $-\mathrm{I}-\left[\mathrm{Cu}(7)\left(\mathrm{CH}_{3} \mathrm{CN}\right)\right]^{2+} \cdot 2 \mathrm{ClO}_{4}{ }^{-}$, with ellipsoids shown at the $50 \%$ probability level. The second perchlorate counterion is not shown.

Like the $[\mathrm{Cu}(7)]^{2+}$ complex dication, the single crystal structure of $[\mathrm{Cu}(\mathbf{8})]^{2+}$ is essentially five coordinate (Figure 5 and SI Figure SX3), with a distorted square pyramidal coordination sphere and a trans-I configuration. ${ }^{39}$ Here though, axial ligation involves the carbonyl oxygen 
of the pendant methyl ester, with a bond length of 2.2477(15) $\AA$ (Table 1). There is then a significant distortion of the coordination geometry, with the macrocycle nitrogen to metal to axial oxygen angles ranging from $78.14(7)$ to $102.41^{\circ}$. This is further reflected in the $\tau$ value of 0.35 . The metal to macrocycle nitrogen distances vary from $2.0529(17)$ to 2.1071(19) $\AA$. There again appears to be a weak interaction, presumably primarily electrostatic, between the metal cation and a perchlorate counterion trans to the pendant carbonyl oxygen, separated by 3.649(2) ^̊.

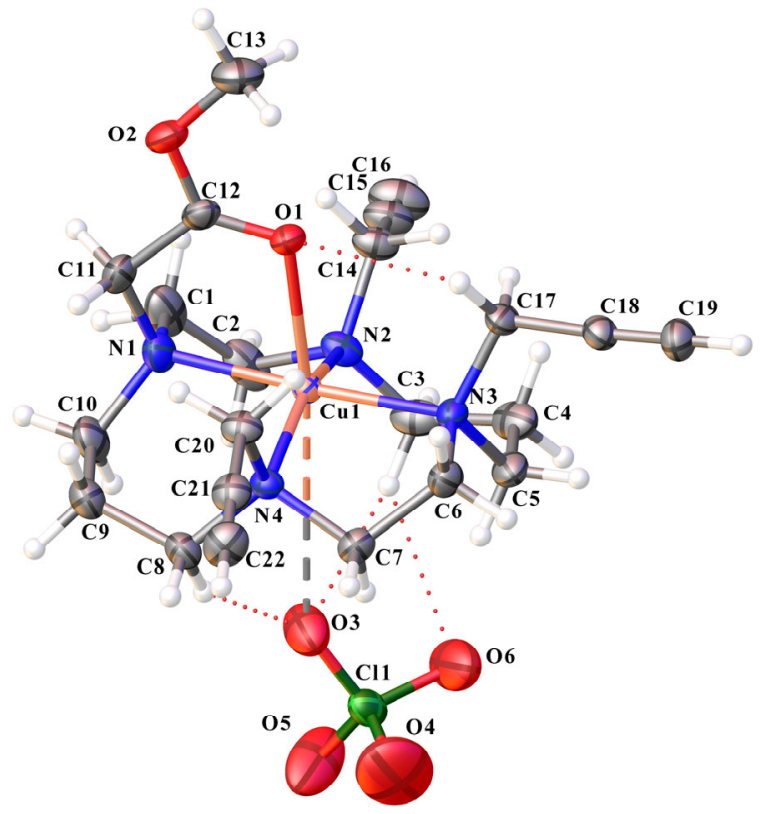

Figure 5. Olex2 depiction of trans $-\mathrm{I}-[\mathrm{Cu}(8)]^{2+} \cdot 2 \mathrm{ClO}_{4}^{-}$, with ellipsoids shown at the $50 \%$ probability level. The second perchlorate counterion is not shown.

\section{Tetra-propargyl Ligand 9 Forms Several Different Cu(II) Complexes}

The crystallisation of $[\mathrm{Cu}(9)]\left(\mathrm{ClO}_{4}\right)_{2}$ produced five visibly distinct crystals in the crystal growth flask (Figure 6). Distinguished here with labels 9A to 9E, the structures obtained from each exhibit significant variation in donor ligand configuration, conformation and even the ligand species, which was surprising given each complex assembly occurred within a single set of components under identical conditions.
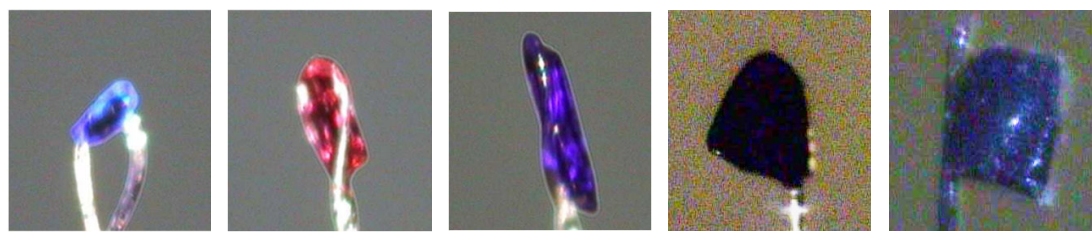

(A)
(B)
(C)
(D)
(E)

Figure 6. Photographs of crystals isolated following the slow diffusion of aqueous $\mathrm{Cu}\left(\mathrm{ClO}_{4}\right)_{2}$ with a methanolic solution of 9: $(\mathbf{9 A})$ trans-I-[Cu(9)](ClO 4$)_{2} ;(\mathbf{9 B})$ trans-III-[Cu(9)](ClO 4$)_{2} ;(\mathbf{9 C})$ trans-I/III$\left([\mathrm{Cu}(9)]\left(\mathrm{ClO}_{4}\right)_{2}\right)_{2} \cdot \mathrm{H}_{2} \mathrm{O}$; (9D) trans-I-[Cu(1,4,8-propargyl-11-(2-methoxypropene)cyclam)](ClO 4$)_{2} \cdot \mathrm{H}_{2} \mathrm{O}$ and (9E) trans-I-[Cu(1,4,8-propargyl-11-(2-methoxypropene)cyclam) $]\left(\mathrm{ClO}_{4}\right)_{2} \cdot 0.25 \mathrm{CH}_{3} \mathrm{OH}$.

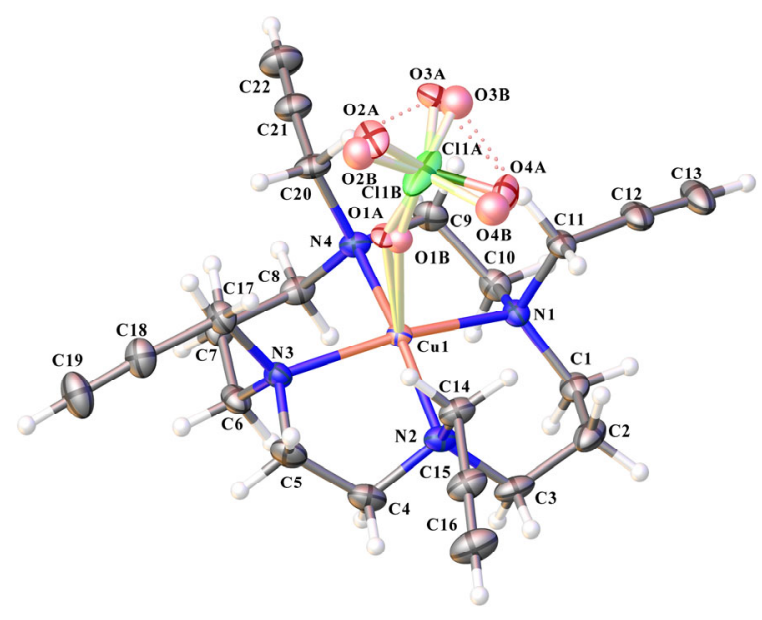

Figure 7. Olex 2 depiction of complex cation $9 \mathrm{~A}$, trans-I- $[\mathrm{Cu}(\mathbf{9})]\left(\mathrm{ClO}_{4}\right)^{+}$, with displacement ellipsoids shown at $50 \%$ probability level. Disordered sites are highlighted with 'faded' colours. The second perchlorate counterion is not shown.

Crystal 9A was found to be that of a trans-I- $[\mathrm{Cu}(9)]\left(\mathrm{ClO}_{4}\right)^{+}$complex cation (Figure 7 and SI Figure SX4, Table 2 and SI Table SX2). The structure geometry is five-coordinate square pyramidal $(\tau=0.03)$, with an axial perchlorate ligand and a coordinated cyclam adopting the favourable trans-I configuration. The metal ion to cyclam nitrogen distances vary from 2.0711(17) to 2.1274(17) $\AA$ (Table 2). The coordinated perchlorate anion is disordered over two orientations (Figure SX4, SI), with coordination bond lengths of 2.359(9) $\AA$ for the major component and 2.301(17) $\AA$ for the minor component. The complex cation is pseudooligomeric, with the copper of one complex cation weakly interacting with the coordinated perchlorate of a second (Figure SX5, SI), with metal to neighbouring perchlorate oxygen distances of approximately $3.51 \AA$ for the major perchlorate orientation and $3.68 \AA$ for the minor orientation.

Crystal 9B was found to comprise a pseudo-octahedral trans-III-[Cu(9)](ClO 4$)_{2}$ complex dication in which axial ligation involves necessarily weak alkyne $\pi$ system coordination. 
Located on an inversion centre, the complex dication has symmetrical bond lengths of approximately $2.93 \AA$ (Figure 8 and SI Figure SX6).

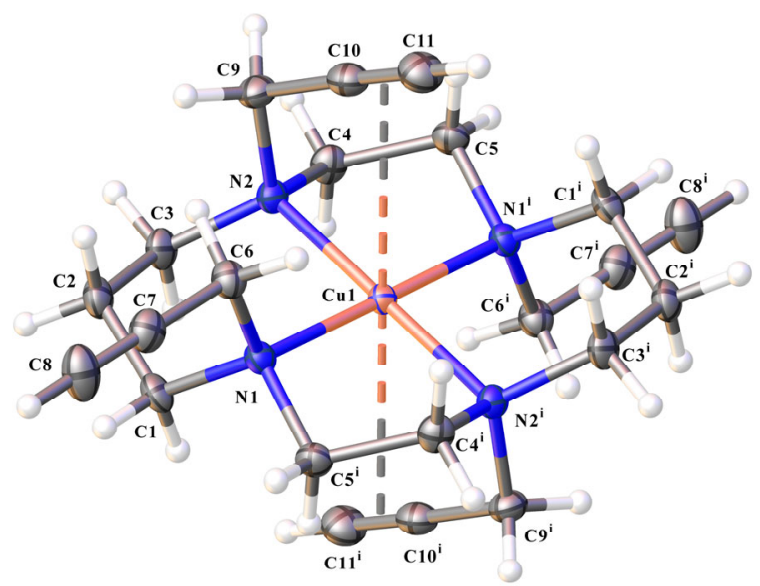

Figure 8. Olex 2 depiction of complex dication 9B trans-III-[Cu(9) $]^{2+}$ with displacement ellipsoids shown at the $50 \%$ probability level. The two perchlorate counterions are not shown. The complex dication resides on an inversion site and the superscript ' $\mathrm{i}$ ' denotes -x, 1-y, -z.

Table 2. Selected bond lengths $(\AA)$ and angles $\left(^{\circ}\right)$ for isolated structures of $[\mathrm{Cu}(\mathbf{9})]^{2+}, \mathbf{9 A}-\mathbf{9 C}$.

\begin{tabular}{|c|c|c|c|c|}
\hline & \multirow{2}{*}{$\begin{array}{c}\mathbf{9 A} \\
\text { trans-I }\end{array}$} & \multirow{2}{*}{$\begin{array}{c}\mathbf{9 B}^{\mathrm{a}} \\
\text { trans }^{-\mathrm{III}}\end{array}$} & \multicolumn{2}{|c|}{$9 \mathrm{C}$} \\
\hline & & & trans-I 9C-1 & trans-III 9C-2 \\
\hline $\mathrm{Cu}-\mathrm{N} 1$ & $2.0711(17)$ & $2.1127(16)$ & $2.059(2)$ & $2.028(2)$ \\
\hline $\mathrm{Cu}-\mathrm{N} 2$ & $2.0959(18)$ & $2.0283(15)$ & $2.061(2)$ & $2.125(2)$ \\
\hline $\mathrm{Cu}-\mathrm{N} 3$ & $2.0999(18)$ & & $2.063(2)$ & \\
\hline $\mathrm{Cu}-\mathrm{N} 4$ & $2.1274(17)$ & & $2.069(2)$ & \\
\hline $\mathrm{Cu}-\mathrm{O}^{\mathrm{b}}$ & $2.359(9)^{\mathrm{c}}$ & & $2.890(2)$ & \\
\hline $\mathrm{Cu}-\mathrm{O}^{\mathrm{b}}$ & $2.301(17)^{\mathrm{c}}$ & & & \\
\hline $\mathrm{Cu}$-alkyne & & 2.93 & 3.04 & 2.93 \\
\hline $\mathrm{N} 1-\mathrm{Cu}-\mathrm{N} 2$ & $93.87(7)$ & $93.40(6)$ & $94.09(9)$ & $93.87(9)$ \\
\hline $\mathrm{N} 1-\mathrm{Cu}-\mathrm{N} 3$ & $167.92(7)$ & & $169.76(8)$ & \\
\hline $\mathrm{N} 1-\mathrm{Cu}-\mathrm{N} 4$ & $85.06(7)$ & & $86.57(9)$ & \\
\hline $\mathrm{N} 2-\mathrm{Cu}-\mathrm{N} 3$ & $84.87(7)$ & & $86.41(9)$ & \\
\hline $\mathrm{N} 2-\mathrm{Cu}-\mathrm{N} 4$ & $169.55(7)$ & & $163.81(8)$ & \\
\hline $\mathrm{N} 3-\mathrm{Cu}-\mathrm{N} 4$ & $94.00(7)$ & & $95.81(9)$ & \\
\hline $\mathrm{N} 1-\mathrm{Cu} 1-\mathrm{O}^{\mathrm{b}}$ & & & $98.48(7)$ & \\
\hline $\mathrm{N} 2-\mathrm{Cu} 1-\mathrm{O}^{\mathrm{b}}$ & & & $81.49(7)$ & \\
\hline $\mathrm{N} 3-\mathrm{Cu} 1-\mathrm{O}^{\mathrm{b}}$ & & & $91.72(7)$ & \\
\hline $\mathrm{N} 4-\mathrm{Cu} 1-\mathrm{O}^{\mathrm{b}}$ & & & $82.41(7)$ & \\
\hline
\end{tabular}

${ }^{a}$ Third and fourth nitrogen sites generated through inversion operation 1-x, 1-y, 1-z; ${ }^{b}$ oxygen sites of perchlorate; ${ }^{\mathrm{c}}$ disordered perchlorate; ${ }^{\mathrm{d}}$ Third and fourth nitrogen sites generated through inversion operation $\mathrm{x}, 1-\mathrm{y},-\mathrm{z}$. 
Crystal 9C was found to contain two chemically and crystallographically distinct $[\mathrm{Cu}(\mathbf{9})]\left(\mathrm{ClO}_{4}\right)_{2}$ complex molecules, for convenience labelled as $\mathbf{9 C - 1}$ and $\mathbf{9 C - 2}$, and a water molecule. The 9C-1 complex molecule is pseudo-octahedral in character, with weak axial perchlorate coordination trans to weak $\pi$ coordination from an $N$-propargyl residue (Figure 9 and SI Figure SX7a). The cyclam complex has a trans-I disposition. The metal to perchlorate oxygen atom distance is $2.890(2) \AA$ and the metal to $\pi$-bond distance is approximately 3.04 $\AA$. The metal to cyclam nitrogen distances range from 2.059 (2) to 2.069(2) $\AA$, with the shortest associated with the weakly coordinated alkyne substituent.

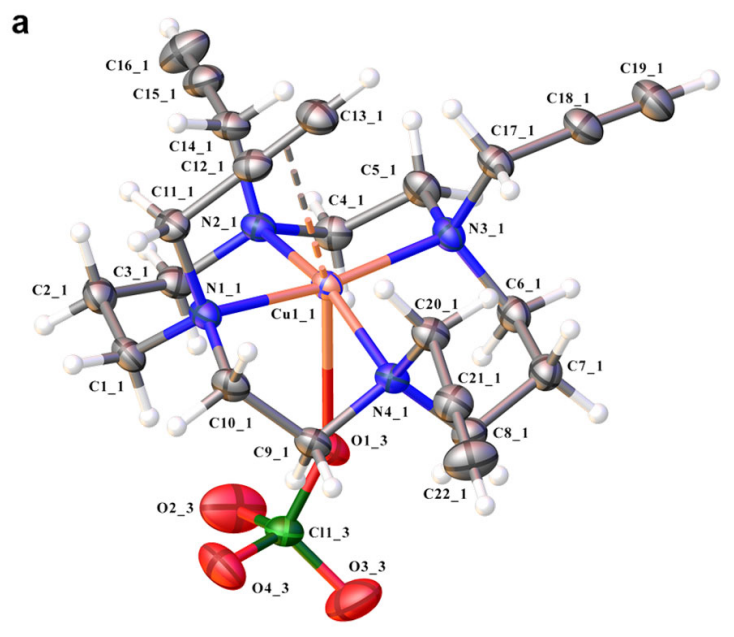

b

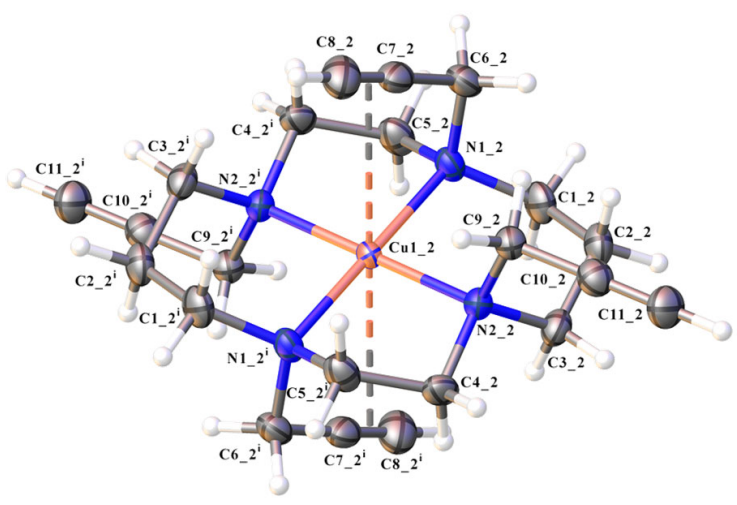

Figure 9. Olex2 depictions of (a) complex 9C-1 trans- $\mathrm{I}-[\mathrm{Cu}(\mathbf{9})]\left(\mathrm{ClO}_{4}\right)^{+}$and (b) complex dication 9C-2 transIII-Cu(9) $]^{2+}$, with displacement ellipsoids shown at the $50 \%$ probability level. The perchlorate counterions are not shown. 
The 9C-2 complex molecule is also pseudo-octahedral in character, but with bis axial 1,8-Npropargyl $\pi$ coordination and a trans-III macrocycle configuration (Figure 9 and SI Figure SX7b). Residing on an inversion centre, the complex has symmetrical and necessarily weak axial coordination bonds of approximately $2.93 \AA$. Located on an inversion centre, the unique metal to cyclam nitrogen distances are 2.028(2) and 2.125(2) A (Table 2).

Both located on inversion sites, the structural features of the pseudo octahedral trans-III 9C2 dication are similar to those of the pseudo octahedral trans-III 9B complex dication (Table 2). Not surprisingly, the structural features of the pseudo octahedral trans-I 9C-1 complex cation differ significantly from those of the square pyramidal trans-I 9A perchlorato complex cation.

\section{An Unexpected Enol Ether}

The fourth and fifth isolated crystal types, 9D and 9E (Figure 10, SI Figures SX8 and SX9, and SI Table SX2), were found to contain copper cyclam complex cations in which one of the pendant propargyl residues is unexpectedly replaced by an enol ether. It would appear that hydroalkoxylation of the alkyne has occurred to form an enol ether, 13, via reaction with the methanol solvent. Recrystallisation of $\mathrm{Cu}(9)$ from other alcohols was investigated, but no corresponding hydroalkoxylation reaction was observed in solvents other than methanol.

High resolution mass spectrometry of material from the same crystal batch supports the single crystal structure determinations, returning molecular ion peaks at 223.60899, 224.11072, 224.60813, and $225.10993\left([\mathrm{M}]^{2+}\right.$ for $\mathrm{C}_{23} \mathrm{H}_{36} \mathrm{CuN}_{4} \mathrm{O}^{2+}$ calculated as 223.60925, 224.11039, $224.60780,225.10948)$ with the correct isotope patterns.

a

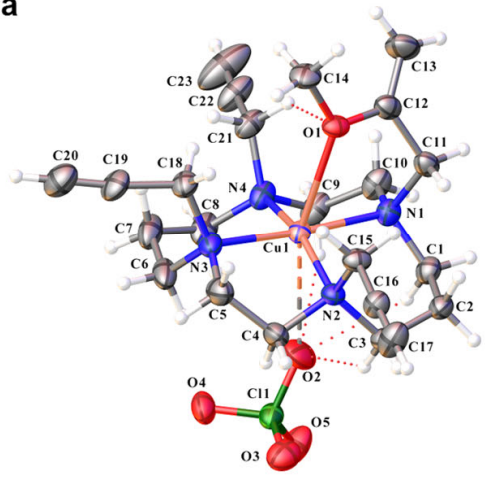

b

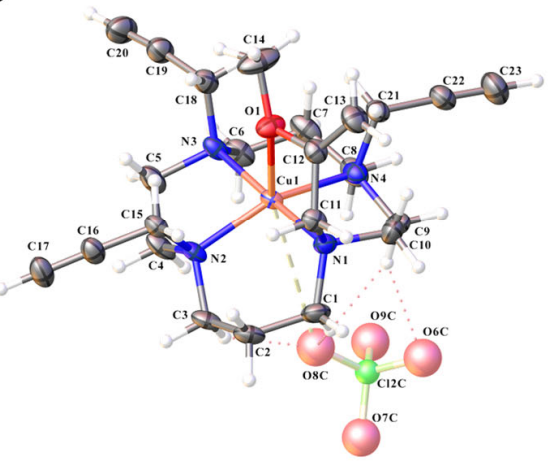

C

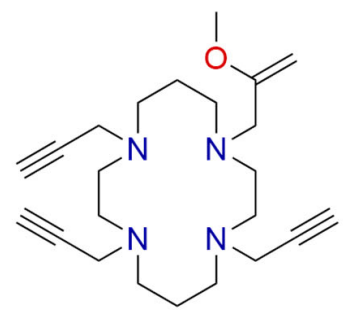

13 
Figure 10. Olex2 depictions of the structures obtained from (a) crystal 9D and (b) crystal 9E of trans-I-[Cu(1(2-methoxyallyl)-4,8,11-tri(prop-2-yn-1-yl)-1,4,8,11-tetraazacyclotetradecane $]^{2+}, \quad\left([\mathrm{Cu}(\mathbf{1 3})]^{2+}\right)$. Displacement ellipsoids are shown at the $30 \%$ and 50\% probability level respectively in (a) and (b). The second perchlorate is not shown in both cases, and nor is a water molecule in crystal 9D and a methanol solvate in crystal 9E. Disorder is highlighted with 'faded' colours. The formed enol ether $\mathbf{1 3}$ is depicted in (c).

Table 3. Selected bond lengths $(\AA)$ and angles $\left({ }^{\circ}\right)$ for isolated structures of $[\mathrm{Cu}(\mathbf{9})]^{2+}, \mathbf{9 D}$ and $\mathbf{9 E}$.

\begin{tabular}{|c|c|c|}
\hline & $\begin{array}{c}\text { 9D } \\
\text { trans }-\mathrm{I}\end{array}$ & $\begin{array}{c}\mathbf{9 E}^{\mathrm{a}} \\
\text { trans }-\mathrm{I}\end{array}$ \\
\hline $\mathrm{Cu}-\mathrm{N} 1$ & $2.078(3)$ & $2.084(2)$ \\
\hline $\mathrm{Cu}-\mathrm{N} 2$ & $2.048(3)$ & $2.047(2)$ \\
\hline $\mathrm{Cu}-\mathrm{N} 3$ & $2.089(3)$ & $2.109(2)$ \\
\hline $\mathrm{Cu}-\mathrm{N} 4$ & $2.089(3)$ & $2.057(2)$ \\
\hline $\mathrm{Cu}-\mathrm{O}$ (ether) & $2.574(2)$ & $2.607(2)$ \\
\hline $\mathrm{Cu}-\mathrm{O}\left(\mathrm{ClO}_{4}^{-}\right)$ & $3.200(4)$ & $3.883(10)^{\mathrm{a}}$ \\
\hline $\mathrm{N} 1-\mathrm{Cu}-\mathrm{N} 2$ & $95.16(13)$ & $94.59(9)$ \\
\hline $\mathrm{N} 1-\mathrm{Cu}-\mathrm{N} 3$ & 175.37(13) & $175.42(9)$ \\
\hline $\mathrm{N} 1-\mathrm{Cu}-\mathrm{N} 4$ & $85.52(13)$ & $86.14(10)$ \\
\hline $\mathrm{N} 2-\mathrm{Cu}-\mathrm{N} 3$ & $86.09(14)$ & $85.51(9)$ \\
\hline $\mathrm{N} 2-\mathrm{Cu}-\mathrm{N} 4$ & $161.59(12)$ & $157.80(9)$ \\
\hline $\mathrm{N} 3-\mathrm{Cu}-\mathrm{N} 4$ & $94.70(15)$ & $95.51(10)$ \\
\hline N1-Cu1-O (ether) & $74.34(11)$ & $74.39(8)$ \\
\hline N2-Cu1-O (ether) & $99.14(10)$ & $101.87(9)$ \\
\hline N3-Cu1-O (ether) & $101.07(11)$ & $101.10(8)$ \\
\hline N4-Cu1-O (ether) & $98.75(11)$ & $99.69(8)$ \\
\hline $\mathrm{N} 1-\mathrm{Cu} 1-\mathrm{O}\left(\mathrm{ClO}_{4}^{-}\right)$ & $85.92(12)$ & $80.8(2)^{\mathrm{a}}$ \\
\hline $\mathrm{N} 2-\mathrm{Cu} 1-\mathrm{O}\left(\mathrm{ClO}_{4}^{-}\right)$ & $83.82(12)$ & $79.41(18)^{\mathrm{a}}$ \\
\hline $\mathrm{N} 3-\mathrm{Cu} 1-\mathrm{O}\left(\mathrm{ClO}_{4}^{-}\right)$ & $98.65(12)$ & $103.7(2)^{\mathrm{a}}$ \\
\hline $\mathrm{N} 4-\mathrm{Cu} 1-\mathrm{O}\left(\mathrm{ClO}_{4}^{-}\right)$ & $77.88(12)$ & $78.81(18)^{\mathrm{a}}$ \\
\hline
\end{tabular}

${ }^{\mathrm{a}}$ Disordered perchlorate orientation with shortest metal to oxygen distance

Differing in colour intensity, the asymmetric unit of 9D contains a water molecule, while that of 9E instead contains a methanol solvent molecule. While both have axial ether coordination and a trans axial interaction with one of the two perchlorate counterions, there is a significant difference in the nature of their respective perchlorate interactions. The axially positioned perchlorate of 9D is ordered, while that of 9E is disordered. Further, the metal to perchlorate oxygen separation in 9D is $3.200(4) \AA$, whereas the shortest metal to perchlorate oxygen distance in 9E is 3.883(10) $\AA$ (Table 3). While the latter presumably reflects an electrostatic interaction, the shorter distance in 9D suggests some degree of covalent coordination. The copper to ether oxygen distance in 9D is 2.574(2) $\AA$, slightly shorter than in 9E at 2.607(2) $\AA$. 
The two complex cations are distorted square pyramidal in character, though 9D may be regarded as pseudo octahedral. The trigonal index $(\tau)$ of $9 \mathbf{D}$ is 0.23 , while that of $\mathbf{9 E}$ is 0.29 . The cyclam nitrogen to copper to ether oxygen angles vary in 9D from 74.34(11) to $101.07(11)^{\circ}$, and in $9 \mathbf{E}$ they range from $74.39(8)$ to $101.87(9)^{\circ}$. The metal to cyclam nitrogen distances in 9D vary from 2.048(3) to 2.089(3) $\AA$, and in 9E these distances span from 2.047(2) to $2.109(2) \AA$.

\section{A Mechanism for Hydroalkoxylation}

The intramolecular copper-mediated hydroalkoxylation event observed and characterised by $\mathrm{X}$-ray crystallography is an intriguing outcome. Although various examples of metal-catalysed alkyne hydroalkoxylation reactions have been reported, relatively few of these are intermolecular. ${ }^{40}$ The addition of alcohols to alkynes is typically achieved using a palladium catalyst, ${ }^{41}$ however examples of copper-activated hydroalkoxylation have been reported. Copper-catalysed intramolecular hydroalkoxylations have been used in the synthesis of benzofurans other heteroaromatic systems. ${ }^{42,}{ }^{43}$ Bertz et al. reported a rare example of intermolecular hydroalkoxylation, in which ethanol was added to ethyl propiolate in the presence of copper(II) sulfate to generate ethyl 3,3-diethoxypropionate. ${ }^{44}$ While Kang and coworkers recently reported the related reaction of exogenous primary amines (benzyl amine or $n$-propylamine) with pendant alkyne arms on macrocyclic copper(II) and nickel(II) complexes, thus achieving hydroamination of the alkyne pendant. ${ }^{45}$

Late transition metal-catalysed alkyne hydroalkoxylation reactions are usually envisaged to proceed via coordination of the pendant $\pi$ system to the metal, which activates the alkyne and enables nucleophilic attack by the alkoxy group. ${ }^{46,47}$ A plausible mechanism for the formation of $[\mathrm{Cu}(\mathbf{1 3})]^{2+}$ from $[\mathrm{Cu}(9)]^{2+}$ in this way is outlined in Scheme 3. However the structural data obtained for $[\mathrm{Cu}(9)]^{2+}$ reveal only weak coordination between alkyne and the copper centre with ligand 9 in the solid state (crystal B, Figure 8), with the perchlorate counterion competing for copper coordination with the alkyne (crystal A, Figure 7). This suggests either that transient alkyne coordination to copper occurs to enable the attack by methanol (Scheme 3, top path), or that the observed hydroalkoxylation follows an alternative mechanism, perhaps via formation of a copper-alkoxide species through coordination of methanol to the copper, 
and nucleophilic attack of this on the uncoordinated alkyne, with perchlorate facilitating the required proton transfer (Scheme 3, bottom path).

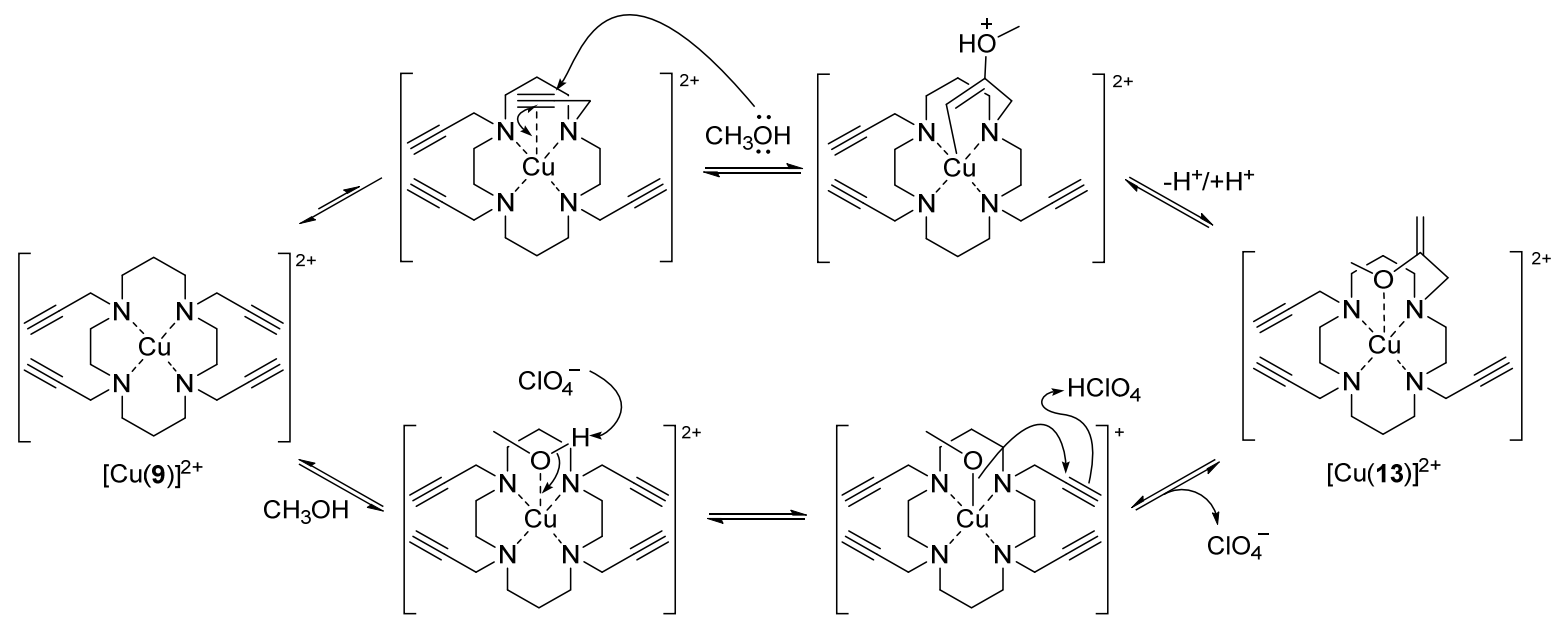

Scheme 3. Proposed mechanism for formation of enol ether complex $[\mathrm{Cu}(\mathbf{1 3})]^{2+}$ from the reaction of $[\mathrm{Cu}(\mathbf{9})]^{2+}$ with the solvent methanol. Top: reaction via transient alkyne coordination to the metal, which enables attack by methanol on the $\pi$ system; bottom: reaction to form a copper-alkoxide species via coordination of methanol to the metal, followed by nucleophilic attack of this on the uncoordinated alkyne (which approximates to an allowed 5-exo-dig cyclisation).

\section{UV-visible Spectroscopy}

UV-visible spectra of $\mathrm{Cu}(\mathrm{II})$ complexes of 6-9 in methanol were obtained; absorption maxima are presented in Table 4. The electronic spectrum of each complex exhibits an intense ligandto-metal charge transfer (LCMT) band in the UV region $(264-307 \mathrm{~nm}),{ }^{48}$ alongside a comparatively weaker absorption band in the visible region $(536-606 \mathrm{~nm})$ corresponding to $\mathrm{Cu}(\mathrm{II}) \mathrm{d}-\mathrm{d}$ transitions. $\lambda_{\max }$ values for all transitions are typical of $N$-alkylated cyclam derivatives. $^{32}$ A bathochromic shift is observed as the number of functionalised amine increases from the mono- $N$-functionalised $[\mathrm{Cu}(6)]^{2+}$, to the complexes of the tetra- $N$-alkylated ligands 7-9. Little difference in the $\mathrm{d}$-d transition energy is observed between $[\mathrm{Cu}(7)]^{2+}$ and $[\mathrm{Cu}(9)]^{2+}$, which suggests that any $\mathrm{Cu}(\mathrm{II})$-propargyl interaction which may occur is limited to two pendants. As expected, replacement of a propargyl group with a methyl ester in $[\mathrm{Cu}(\mathbf{8})]^{2+}$ results in a further red shift. The relative strength of the coordination environments around the central $\mathrm{Cu}$ (II) ion exhibited in the structural data (above) is consistent with the d-d transition energies observed in the spectra, with the latter increasing alongside the strength of pendant coordination. 
Table 4. Electronic absorption data for $\mathrm{Cu}(\mathrm{II})$ complexes of compounds $\mathbf{6}-\mathbf{9}$ and $\mathbf{1 4}$ in $\mathrm{CH}_{3} \mathrm{OH}$ (unless otherwise indicated)

\begin{tabular}{l|l}
\hline Complex & $\underline{\lambda_{\max } / \mathrm{nm}\left(\varepsilon / \mathrm{M}^{-1} \cdot \mathrm{cm}^{-1}\right)}$ \\
\hline$[\mathrm{Cu}(\mathbf{6})]^{2+}$ & $264(6569), 536(114)$ \\
\hline$[\mathrm{Cu}(7)]^{2+}$ & $303(8240), 541(164)$ \\
\hline$[\mathrm{Cu}(\mathbf{8})]^{2+}$ & $296(6990), 606(204)$ \\
\hline$[\mathrm{Cu}(\mathbf{9})]^{2+}$ & $307(7609), 543(147)$ \\
\hline$[\mathrm{Cu}(\mathbf{1 4})]^{2+}$ & $316(6494), 654(286)^{\mathrm{a}}$ \\
\hline
\end{tabular}

${ }^{\mathrm{a}} \mathrm{DMF}$ used as solvent.

\section{Derivatisation of Tetra-propargyl Derivative 9}

To demonstrate the utility of $\mathbf{9}$ as a precursor to more complex tetra-functionalised cyclam derivatives, the 'tetra-click' tetra-triazolyl cyclam species $\mathbf{1 4}$ was synthesised via a copper(I)catalysed azide-alkyne cycloaddition (CuAAC) of 9 with benzyl azide (Scheme 4a). To minimise the sequestration of the copper(I) catalyst by the macrocyclic starting material and product, copper(I) iodide - relatively insoluble in most organic solvents - was used as a heterogeneous catalyst. Monitoring the reaction mixture via mass spectrometry indicated that sequestration of the catalyst did occur to some extent. However, the tetra-click product $\mathbf{1 4}$ could be isolated in moderate yield ( $46 \%$ on $100 \mathrm{mg}$ scale, $30 \%$ on $0.50 \mathrm{~g}$ scale) by collecting the precipitate formed during the reaction and subjecting this directly to flash column chromatography over silica. Accordingly, a convergent route to $\mathbf{1 4}$ was developed (Scheme 4b), with a view that an increased yield could be achieved if the CuACC was conducted in the absence of the cyclam. Bromide $\mathbf{1 6}$ was formed in two steps from benzyl azide, ${ }^{49}$ and in the critical step, used to alkylate cyclam 1 in good yield (71\%). 

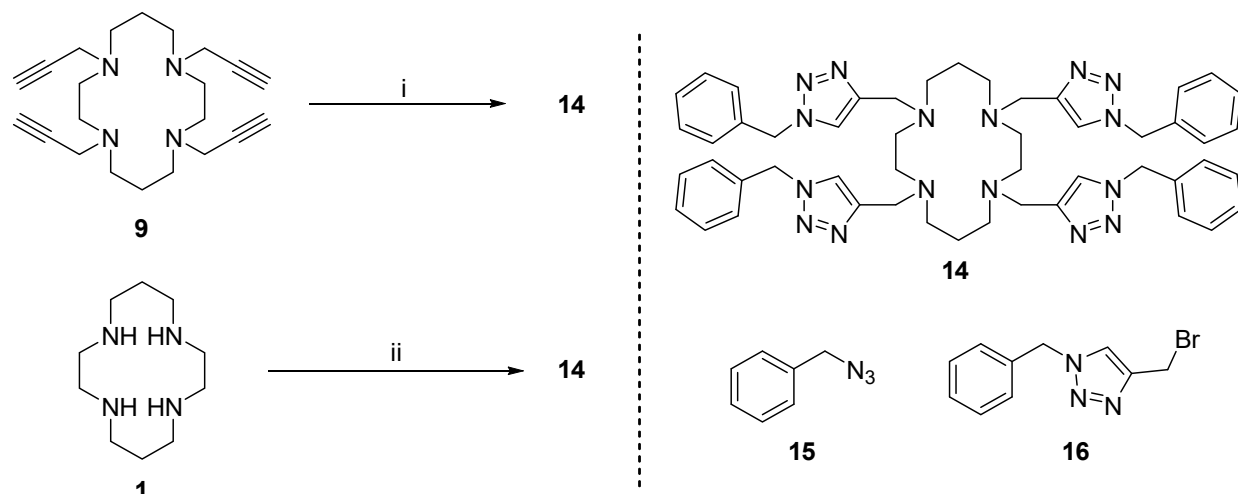

Scheme 4. Synthesis of 'tetra-click' tetra-triazolyl cyclam 14. Reagents and conditions: (i) benzyl azide 15, CuI, sodium ascorbate, DIPEA, THF, rt, $5 \mathrm{~d}, 30 \%$; (ii) bromide 16, $\mathrm{H}_{2} \mathrm{O}: \mathrm{CH}_{3} \mathrm{CN}(1: 1), \mathrm{NaOH}, \mathrm{rt}, 16 \mathrm{~h}, 71 \%$.

The spectroscopic properties of $\mathbf{1 4}$ were investigated alongside $\mathbf{9}$ for comparison. The stoichiometry of complexation of both 9 and 14 with $\mathrm{Cu}(\mathrm{II})$ was investigated by UV-visible spectrophotometric titrations, and returned results that are consistent with previous studies on similar cyclam ligands. ${ }^{20,27,32}$ The UV-visible titration of 9 in methanol with $\mathrm{Cu}\left(\mathrm{ClO}_{4}\right)_{2}$ showed the absorbances at 307 and $543 \mathrm{~nm}$ steadily increasing with the addition of $\mathrm{Cu}\left(\mathrm{ClO}_{4}\right)_{2}$, to reach their maxima upon the addition of one equivalent of $\mathrm{Cu}(\mathrm{II})$ (Figure 11). No significant increase in absorbance at either wavelengths was observed with further addition of $\mathrm{Cu}(\mathrm{II})$. Similar observations were made in the titration of 14 in DMF with $\mathrm{Cu}\left(\mathrm{ClO}_{4}\right)_{2}$ (Figure 12). Job's plot experiments confirmed each stoichiometric ratio to be 1:1 (Figure S1, SI).

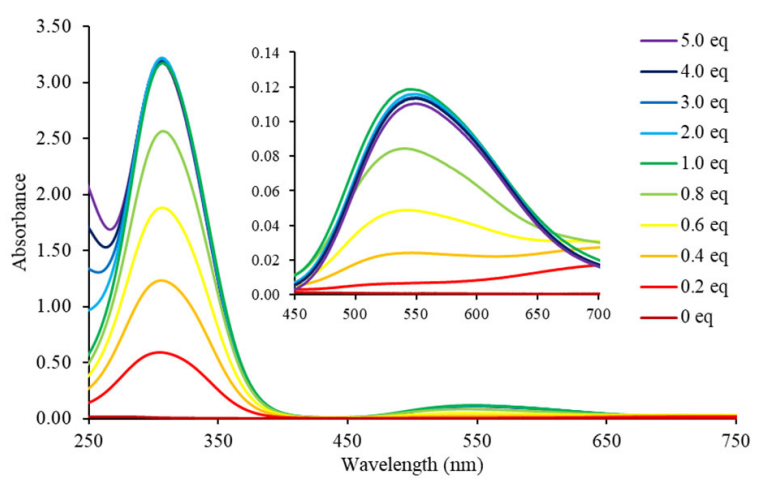

Figure 11. UV-vis spectrophotometric titrations of $9(1 \mathrm{mM})$ with $\mathrm{Cu}\left(\mathrm{ClO}_{4}\right)_{2}(50 \mathrm{mM})$ at intervals of $5 \mathrm{~min}$ in $\mathrm{CH}_{3} \mathrm{OH}$ at $25^{\circ} \mathrm{C}$, with inset enlarging the region between $450-700 \mathrm{~nm}$. 


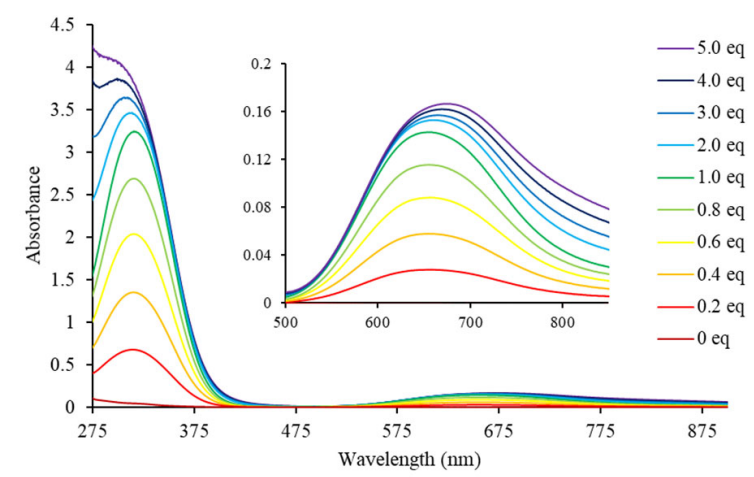

Figure 12. UV-vis spectrophotometric titrations of $\mathbf{1 4}(0.5 \mathrm{mM})$ with $\mathrm{Cu}\left(\mathrm{ClO}_{4}\right)_{2}(50 \mathrm{mM})$ at intervals of $5 \mathrm{~min}$ in DMF at $25^{\circ} \mathrm{C}$, with inset enlarging the region between $500-850 \mathrm{~nm}$.

\section{CONCLUSIONS}

Four $N$-propargyl cyclam ligands have been synthesised and their copper complexes investigated. To the best of our knowledge, crystal $\mathbf{B}$ of $[\mathrm{Cu}(\mathbf{9})]\left(\mathrm{ClO}_{4}\right)_{2}$ constitutes the first cyclam derivative to exhibit intramolecular non-acetylide alkyne coordination, although this coordination is weak. Several ligand systems have been reported previously to exhibit monomeric $\eta^{2}$-alkyne coordination, ${ }^{50,51}$ including the notable alkyne 'cages',52, 53 and organometallic acetylide cyclam complexes. ${ }^{54,55} \mathrm{Xu}$ and Chao prepared the $\mathrm{Nd}(\mathrm{III})$ complex of tetra- $N$-propargyl cyclen, however none of the pendant alkynes were coordinated to the metal in that complex. ${ }^{56}$ Similarly, a variety of alkyne-containing cyclen-based lanthanoid complexes investigated by Milne et al. did not exhibit alkyne coordination to the metal. ${ }^{57}$ Ellis et al. successfully prepared a series of alkyne-containing $N$-alkylated derivatives of the 9membered $N, N^{\prime}, N$ '-1,4,7-triazacyclononane ring system, however they did not isolate any metal complexes. ${ }^{58}$ A search of the Cambridge Structural Database yields few examples of amine-bound metal ions with a coordinating alkyne connected through the chelator backbone. Aurora et al. isolated a $\mathrm{Cu}(\mathrm{II})$ polyamido complex containing a $C$-propargyl group which exhibited a weak apical interaction between alkyne and metal with $\mathrm{C}-\mathrm{Cu}$ distances of 2.805(4) and 2.737(4) $\AA .{ }^{37}$ Seebald et al. recently reported the structure of a mono- $N$-propargyl cobalt(II) cyclam complex, designed for use as an NMR probe, ${ }^{59}$ and there are a small number of other examples in the literature of more heavily functionalised azamacrocycles bearing pendant $N$-propargyl groups. ${ }^{45,60}$ Intramolecular $\eta^{2}$-alkyne interactions were also recently observed in a series of coordinated lithium acetylide complexes. ${ }^{61}$ 
In addition, we have observed the isolation of multiple crystals of $[\mathrm{Cu}(9)]\left(\mathrm{ClO}_{4}\right)_{2}$ from a single recrystallisation, with each structure exhibiting a unique coordination complex, configuration, or conformation of the ligand 9 . The formation of a collection of distinct species from a single set of components suggests that the complexes are similar energetically.

Finally the 'tetra-click' reaction of $\mathbf{9}$ with benzyl azide to form tetra-triazole $\mathbf{1 4}$ provides proof of concept for the straightforward derivatisation of the tetra- $N$-propargyl ligand $\mathbf{9}$, which will enable further developments in the design and synthesis of macrocyclic metal ion sensors, and target-activated metal complexes for biomedical applications.

\section{EXPERIMENTAL}

\section{Synthetic Procedures}

Synthetic procedures and characterisation data for ligands are detailed in the Supporting Information.

\section{General Procedure for Preparation of Metal Complexes}

To a solution of $N$-functionalised cyclam $(1.0 \mathrm{eq})$ in EtOH $(0.1 \mathrm{M})$ was added dropwise a solution $\mathrm{Cu}\left(\mathrm{ClO}_{4}\right)_{2} \cdot 6 \mathrm{H}_{2} \mathrm{O}(0.8-1.0 \mathrm{eq})$ in $\mathrm{EtOH}(0.1 \mathrm{M})$ at room temperature. The reaction mixture was heated at reflux for $1 \mathrm{~h}$, cooled on an ice bath and the solvent was decanted. The remaining residue was washed with ice-cold $\mathrm{EtOH}(3 \times 20 \mathrm{~mL})$ and $\mathrm{Et}_{2} \mathrm{O}(3 \times 20 \mathrm{~mL})$, and dried in vacuo to give the desired metal complex.

$[\mathrm{Cu}(6)]\left(\mathrm{ClO}_{4}\right)_{2}$

Ligand $6(128 \mathrm{mg}, 0.537 \mathrm{mmol})$ and $\mathrm{Cu}\left(\mathrm{ClO}_{4}\right)_{2} \cdot 6 \mathrm{H}_{2} \mathrm{O}(160 \mathrm{mg}, 0.432 \mathrm{mmol})$ were complexed according to the general complexation procedure to give $[\mathrm{Cu}(6)]\left(\mathrm{ClO}_{4}\right)_{2}$ as a purple-pink powder $(173 \mathrm{mg}, 80 \%)$. m.p. $264-265^{\circ} \mathrm{C}$. UV-Vis $\left(\mathrm{CH}_{3} \mathrm{OH}\right) \lambda_{\max } / \mathrm{nm}\left(\varepsilon / \mathrm{M}^{-1} \cdot \mathrm{cm}^{-1}\right) 264(6569)$; 536 (114). IR $v_{\max } / \mathrm{cm}^{-1} 3548,3241,2929,2888,1632,1429,1367,1297,1236,1057,619$. HRMS (ESI+) m/z 400.09330, 401.09699, 402.09102, 403.09476, 404.08847, 405.08847, $405.09208\left(\left[\mathrm{M}-\mathrm{ClO}_{4}\right]^{+}\right)$; calcd. for $\mathrm{C}_{13} \mathrm{H}_{26} \mathrm{ClCuN}_{4} \mathrm{O}_{4}{ }^{+}$400.09331, 401.09667, 402.09150, 403.09486, 404.08855, 405.08XYZ, 405.09191 $\left(\left[\mathrm{M}-\mathrm{ClO}_{4}\right]^{+}\right)$. Anal. Calcd. for $\mathrm{C}_{13} \mathrm{H}_{26} \mathrm{Cl}_{2} \mathrm{CuN}_{4} \mathrm{O}_{8} \cdot \mathrm{CH}_{3} \mathrm{OH}$ : C 31.56, N 10.51, H 5.68; found C 31.74, N 10.77, H 5.48. 


\section{$[\mathrm{Cu}(7)]\left(\mathrm{ClO}_{4}\right)_{2}$}

Ligand $7(20 \mathrm{mg}, 0.072 \mathrm{mmol})$ and $\mathrm{Cu}\left(\mathrm{ClO}_{4}\right)_{2} \cdot 6 \mathrm{H}_{2} \mathrm{O}(27 \mathrm{mg}, 0.072 \mathrm{mmol})$ were complexed according to the general complexation procedure to give $[\mathrm{Cu}(7)]\left(\mathrm{ClO}_{4}\right)_{2}$ as a purple solid $(33$ mg, 81\%). m.p. $131-134{ }^{\circ} \mathrm{C}$ (decomposed). UV-Vis $\left(\mathrm{CH}_{3} \mathrm{OH}\right) \lambda_{\max } / \mathrm{nm}\left(\varepsilon / \mathrm{M}^{-1} \cdot \mathrm{cm}^{-1}\right) 303$ (8240); 541 (164). IR $v_{\max } / \mathrm{cm}^{-1} 3504,3243,2936,2269,1653,1477,1370,1340,1072,996$, 956, 931, 861, 835, 797, 727, 673, 620, 537, 497, 469. HRMS (ESI+) $\mathrm{m} / z$ 466.14011, 467.14343, 468.13853, 469.14182, 470.13540, 471.13843 [M-ClO $]^{+}$; calcd. for $\mathrm{C}_{18} \mathrm{H}_{32} \mathrm{ClCuN}_{4} \mathrm{O}_{4}{ }^{+}$466.14026, 467.14362, 468.13832, 469.14178, 470.13550, 471.13886 [M$\left.\mathrm{ClO}_{4}\right]^{+}$. Anal. Calcd. For $\mathrm{C}_{18} \mathrm{H}_{32} \mathrm{Cl}_{2} \mathrm{CuN}_{4} \mathrm{O}_{8} \cdot \mathrm{H}_{2} \mathrm{O}$ : C 36.96, N 9.58, H 5.86; found C 37.12, N 9.51, H 5.51.

$[\mathrm{Cu}(\mathbf{8})]\left(\mathrm{ClO}_{4}\right)_{2}$

Ligand $8(20 \mathrm{mg}, 0.052 \mathrm{mmol})$ and $\mathrm{Cu}\left(\mathrm{ClO}_{4}\right)_{2} \cdot 6 \mathrm{H}_{2} \mathrm{O}(19 \mathrm{mg}, 0.052 \mathrm{mmol})$ were complexed according to the general complexation procedure to give $[\mathrm{Cu}(\mathbf{8})]\left(\mathrm{ClO}_{4}\right)_{2}$ as a blue solid $(26$ mg, 77\%). m.p. $118-121{ }^{\circ} \mathrm{C}$ (decomposed). UV-Vis $\left(\mathrm{CH}_{3} \mathrm{OH}\right) \lambda_{\max } / \mathrm{nm}\left(\varepsilon / \mathrm{M}^{-1} \cdot \mathrm{cm}^{-1}\right) 296$ (6990); 606 (204). IR $v_{\max } / \mathrm{cm}^{-1}$ 3265, 2971, 2119, 1683, 1603, 1456, 1388, 1340, 1302, 1272, 1252, 1081, 991, 959, 930, 912, 808, 729, 672, 622. HRMS (ESI+) $m / z$ 548.14545, 549.14882, 550.14322, 551.14656, 522.14069, 553.14391 [M-ClO 4$]^{+}$; calcd. for $\mathrm{C}_{22} \mathrm{H}_{34} \mathrm{ClCuN}_{4} \mathrm{O}_{6}{ }^{+}$ 548.14574, 549.14910, 550.14381, 551.14726, 552.14099, 553.14434 [M-ClO $]^{+}$. Anal. Calcd. for $\mathrm{C}_{22} \mathrm{H}_{34} \mathrm{Cl}_{2} \mathrm{CuN}_{4} \mathrm{O}_{10} \cdot \mathrm{H}_{2} \mathrm{O}$ : C 39.62, N 8.40, H 5.44. Found: C 39.99, N 8.28, H 5.24.

$[\mathrm{Cu}(\mathbf{9})]\left(\mathrm{ClO}_{4}\right)_{2}$

Ligand $9(50 \mathrm{mg}, 0.14 \mathrm{mmol})$ and $\mathrm{Cu}\left(\mathrm{ClO}_{4}\right)_{2} \cdot 6 \mathrm{H}_{2} \mathrm{O}(52 \mathrm{mg}, 0.14 \mathrm{mmol})$ were complexed according to the general complexation procedure to give $[\mathrm{Cu}(9)]\left(\mathrm{ClO}_{4}\right)_{2}$ as a blue solid $(69$ mg, 80\%). m.p. $118-120{ }^{\circ} \mathrm{C}$ (decomposed). UV-Vis $\left(\mathrm{CH}_{3} \mathrm{OH}\right) \lambda_{\max } / \mathrm{nm}\left(\varepsilon / \mathrm{M}^{-1} \cdot \mathrm{cm}^{-1}\right) 307$ (7609); 543 (147). IR $v_{\max } / \mathrm{cm}^{-1}$ 3249, 2846, 1678. HRMS (ESI+) $m / z$ 514.14048, 515.14370, 516.13816, 517.14129, 518.13563, 519.13916 [M-ClO 4$]^{+}$; calcd. for $\mathrm{C}_{22} \mathrm{H}_{32} \mathrm{ClCuN}_{4} \mathrm{O}_{4}{ }^{+}$ $514.14026,515.14361,516.13845,517.14181,517.14181,518.13550,519.13886\left[\mathrm{M}-\mathrm{ClO}_{4}\right]^{+}$. Anal. Calcd. for $\mathrm{C}_{22} \mathrm{H}_{32} \mathrm{Cl}_{2} \mathrm{CuN}_{4} \mathrm{O}_{8}$ : C 42.97, $\mathrm{N}$ 9.11, H 5.25. Found: C 43.23, N 9.12, H 5.21.

\section{Crystallography}

Single crystal X-ray diffraction data were collected on an Agilent SuperNova equipped with an Atlas CCD. The crystal was harvested from amongst the diffusion supernatant, and affixed to a thin mohair 
fibre attached to a goniometer head with Exxon Paratone N. The crystal was quenched in a continuous stream of dry $\mathrm{N}_{2}$ regulated by an Oxford Cryosystems Cryostream at 150(2) K. Mirror monochromated $\mathrm{Cu}-\mathrm{K} \alpha$ radiation from a micro-source was used for data collection. Data reduction and finalisation were conducted with CrysAlisPro. ${ }^{61}$ In general, structures were obtained using ShelXS and, in all cases, extended and refined with ShelXL-2018/3. ${ }^{62}$ Computations and image generation were undertaken with the assistance of the WinGX ${ }^{63}$, ShelXle ${ }^{64}$ and Olex $2^{65}$ user interfaces. In general, all non-hydrogen atoms were modelled with anisotropic displacement parameters, and a riding atom model applied for hydrogen atoms.

CCDC reference numbers 2012628-2012634. CIFs can can be obtained free of charge from The Cambridge Crystallographic Data Centre via https://www.ccdc.cam.ac.uk/data request/cif

\section{ACKNOWLEDGEMENTS}

We thank the Australian Research Council for funding through Discovery Project grant DP120104035.

\section{REFERENCES}

1. Rodríguez-Rodríguez, A.; Halime, Z.; Lima, L. M. P.; Beyler, M.; Deniaud, D.; Le Poul, N.; Delgado, R.; Platas-Iglesias, C.; Patinec, V.; Tripier, R. Cyclams with Ambidentate Methylthiazolyl Pendants for Stable, Inert, and Selective $\mathrm{Cu}$ (II) Coordination. Inorg. Chem. 2016, 55 (2), 619-632 DOI: 10.1021/acs.inorgchem.5b01779.

2. Fabbrizzi, L. In Macrocyclic and Supramolecular Chemistry: How Izatt-Christensen Award Winners Shaped the Field; Izatt, R. M., Ed.; 2016; Chapter 8, pp 165-199.

3. Barefield, K. E. Coordination chemistry of $N$-tetraalkylated cyclam ligands - A status report. Coord. Chem. Rev. 2010, 254 (15-16), 1607-1627 DOI: 10.1016/j.ccr.2010.03.007.

4. Kaden, T. A. Synthesis and Metal Complexes of Aza-Macrocycles with Pendant Arms having Additional Ligating Groups. Top. Curr. Chem. 1984, 121, 157-179.

5. Mako, T. L.; Racicot, J. M.; Levine, M. Supramolecular Luminescent Sensors. Chem. Rev. 2019, 119 (1), 322-477 DOI: 10.1021/acs.chemrev.8b00260.

6. Chowdhury, S.; Rooj, B.; Dutta, A.; Mandal, U. Review on Recent Advances in Metal Ions Sensing Using Different Fluorescent Probes. J Fluoresc 2018, 28 (4), 999-1021 DOI: 10.1007/s10895-018-2263-y.

7. Comba, P.; Gahan, L. R.; Hanson, G. R.; Mereacre, V.; Noble, C. J.; Powell, A. K.; Prisecaru, I.; Schenk, G.; Zajaczkowski-Fischer, M. Monoesterase Activity of a Purple Acid Phosphatase 
Mimic with a Cyclam Platform. Chem. Eur. J. 2012, 18 (6), 1700-1710 DOI:

10.1002/chem.201100229.

8. Hubin, T. J.; McCormick, J. M.; Collinson, S. R.; Buchalova, M.; Perkins, C. M.; Alcock, N. W.; Kahol, P. K.; Raghunathan, A.; Busch, D. H. New Iron(II) and Manganese(II) Complexes of Two Ultra-Rigid, Cross-Bridged Tetraazamacrocycles for Catalysis and Biomimicry. J. Am. Chem. Soc 2000, 122 (11), 2512-2522 DOI: 10.1021/ja990366f.

9. Lau, Y. H.; Clegg, J. K.; Price, J. R.; Macquart, R. B.; Todd, M. H.; Rutledge, P. J. Molecular Switches for any $\mathrm{pH}$ : A Systematic Study of the Versatile Coordination Behaviour of Cyclam Scorpionands. Chemistry 2018, 24 (7), 1573-1585 DOI: 10.1002/chem.201703488.

10. Fabbrizzi, L.; Foti, F.; Licchelli, M.; Maccarini, P. M.; Sacchi, D.; Zema, M. Light-Emitting Molecular Machines: pH-Induced Intramolecular Motions in a Fluorescent Nickel(II) Scorpionate Complex. Chem. Eur. J. 2002, 8 (21), 4965-4972 DOI: 10.1002/15213765(20021104)8:21<4965::aid-chem4965>3.0.co;2-x.

11. Martín-Caballero, J.; San José Wéry, A.; Reinoso, S.; Artetxe, B.; San Felices, L.; El Bakkali, B.; Trautwein, G.; Alcañiz-Monge, J.; Vilas, J. L.; Gutiérrez-Zorrilla, J. M. A Robust Open Framework Formed by Decavanadate Clusters and Copper(II) Complexes of Macrocyclic Polyamines: Permanent Microporosity and Catalytic Oxidation of Cycloalkanes. Inorg. Chem. 2016, 55 (10), 4970-4979 DOI: 10.1021/acs.inorgchem.6b00505.

12. Jens, G.; Thomas, W.; Burkhard, K. Transition Metal Complexes of Some Azamacrocycles and Their Use in Molecular Recognition. Curr. Org. Synth. 2007, 4 (4), 390-412 DOI: 10.2174/157017907782408770.

13. Zhu, J.; Usov, P. M.; Xu, W.; Celis-Salazar, P. J.; Lin, S.; Kessinger, M. C.; LandaverdeAlvarado, C.; Cai, M.; May, A. M.; Slebodnick, C.; Zhu, D.; Senanayake, S. D.; Morris, A. J. New class of metal-cyclam-based zirconium metal-organic frameworks for $\mathrm{CO} 2$ adsorption and chemical fixation. J. Am. Chem. Soc. 2018, 140 (3), 993-1003 DOI: 10.1021/jacs.7b10643.

14. Neri, G.; Aldous, I. M.; Walsh, J. J.; Hardwick, L. J.; Cowan, A. J. A highly active nickel electrocatalyst shows excellent selectivity for $\mathrm{CO} 2$ reduction in acidic media. Chem. Sci. 2016, 7 (2), 1521-1526 DOI: 10.1039/c5sc03225c.

15. Hoppe, T.; Schaub, S.; Becker, J.; Würtele, C.; Schindler, S. Characterization of a Macrocyclic end-on Peroxido Copper Complex. Angew. Chem. Int. Ed. 2013, 52 (3), 870-873 DOI: 10.1002/anie.201205663.

16. Konai, M. M.; Pakrudheen, I.; Barman, S.; Sharma, N.; Tabbasum, K.; Garg, P.; Haldar, J. Cyclam-based antibacterial molecules eradicate Gram-negative superbugs with potent efficacy 
against human corneal infection. Chem. Commun. 2020, 56 (14), 2147-2150 DOI:

$10.1039 / \mathrm{c} 9 \mathrm{cc} 06967 \mathrm{~d}$.

17. Clough, T. J.; Jiang, L.; Wong, K. L.; Long, N. J. Ligand design strategies to increase stability of gadolinium-based magnetic resonance imaging contrast agents. Nat. Commun. 2019, 10 (1), DOI: $10.1038 / \mathrm{s} 41467-019-09342-3$.

18. Derrick, J. S.; Lee, J.; Lee, S. J. C.; Kim, Y.; Nam, E.; Tak, H.; Kang, J.; Lee, M.; Kim, S. H.; Park, K.; Cho, J.; Lim, M. H. Mechanistic Insights into Tunable Metal-Mediated Hydrolysis of Amyloid- $\beta$ Peptides. J. Am. Chem. Soc. 2017, 139 (6), 2234-2244 DOI: 10.1021/jacs.6b09681.

19. Pallavicini, P. S.; Perotti, A.; Poggi, A.; Seghi, B.; Fabbrizzi, L. N-(aminoethyl)cyclam: a tetraaza macrocycle with a coordinating tail (scorpiand). Acidity controlled coordination of the side chain to nickel(II) and nickel(III) cations. J. Am. Chem. Soc. 1987, 109 (17), 5139-5144 DOI: $10.1021 / \mathrm{ja} 00251 \mathrm{a} 016$.

20. Lau, Y. H.; Price, J. R.; Todd, M. H.; Rutledge, P. J. A Click Fluorophore Sensor that Can Distinguish CuII and HgII via Selective Anion-Induced Demetallation. Chem. Eur. J. 2011, 17 (10), 2850-2858 DOI: 10.1002/chem.201002477.

21. Ast, S.; Rutledge, P. J.; Todd, M. H. Reversing the Triazole Topology in a Cyclam-TriazoleDye Ligand Gives a 10-Fold Brighter Signal Response to $\mathrm{Zn}^{2+}$ in Aqueous Solution. Eur. J. Inorg. Chem. 2012, 2012 (34), 5611-5615 DOI: 10.1002/ejic.201201072.

22. Wong, J. K.-H.; Ast, S.; Yu, M.; Flehr, R.; Counsell, A. J.; Turner, P.; Crisologo, P.; Todd, M. H.; Rutledge, P. J. Synthesis and evaluation of 1,8-disubstituted-cyclam/ naphthalimide conjugates as probes for metal ions. Chem. Open 2016, 5, 375-385 DOI: 10.1002/open.201600010.

23. Yu, M.; Nagalingam, G.; Ellis, S.; Martinez, E.; Sintchenko, V.; Spain, M.; Rutledge, P. J.; Todd, M. H.; Triccas, J. A. Nontoxic Metal-Cyclam Complexes, a New Class of Compounds with Potency against Drug-Resistant Mycobacterium tuberculosis. J. Med. Chem. 2016, 59 (12), 5917-5921 DOI: 10.1021/acs.jmedchem.6b00432.

24. Spain, M.; Wong, J. K. H.; Nagalingam, G.; Batten, J. M.; Hortle, E.; Oehlers, S. H.; Jiang, X. F.; Murage, H. E.; Orford, J. T.; Crisologo, P.; Triccas, J. A.; Rutledge, P. J.; Todd, M. H. Antitubercular Bis-Substituted Cyclam Derivatives: Structure-Activity Relationships and in Vivo Studies. J. Med. Chem. 2018, 61 (8), 3595-3608 DOI: 10.1021/acs.jmedchem.7b01569.

25. Zhanaidarova, A.; Moore, C. E.; Gembicky, M.; Kubiak, C. P. Covalent attachment of $\left[\mathrm{Ni}(\text { alkynyl-cyclam) }]^{2+}\right.$ catalysts to glassy carbon electrodes. Chem. Commun. 2018, 54 (33), 4116-4119 DOI: 10.1039/C8CC00718G. 
26. Yu, M.; Ast, S.; Yu, Q.; Lo, A. T. S.; Flehr, R.; Todd, M. H.; Rutledge, P. J. Incorporating a piperidinyl group in the fluorophore extends the fluorescence lifetime of click-derived cyclamnaphthalimide conjugates. PLoS One 2014, 9 (7), e100761/1-e100761/12, 12 pp. DOI: 10.1371/journal.pone.0100761.

27. Yu, M.; Lim, N. H.; Ellis, S.; Nagase, H.; Triccas, J. A.; Rutledge, P. J.; Todd, M. H. Incorporation of Bulky and Cationic Cyclam-Triazole Moieties into Marimastat Can Generate Potent MMP Inhibitory Activity without Inducing Cytotoxicity. Chem. Open 2013, 2 (3), 99 105 DOI: 10.1002/open.201300014.

28. Yu, M.; Yu, Q.; Rutledge, P. J.; Todd, M. H. A Fluorescent “Allosteric Scorpionand” Complex Visualizes a Biological Recognition Event. ChemBioChem 2013, 14 (2), 224-229 DOI: 10.1002/cbic.201200637.

29. Struthers, H.; Mindt, T. L.; Schibli, R. Metal Chelating Systems Synthesized Using the Copper(I) Catalyzed Azide-Alkyne Cycloaddition. Dalton Trans. 2010, 39 (3), 675-696 DOI: 10.1039/B912608B.

30. Boschetti, F.; Denat, F.; Espinosa, E.; Tabard, A.; Dory, Y.; Guilard, R. Regioselective $N$ Functionalization of Tetraazacycloalkanes. J. Org. Chem. 2005, 70 (18), 7042-7053 DOI: 10.1021/jo050306u.

31. Counsell, A. J.; Jones, A. T.; Todd, M. H.; Rutledge, P. J. A direct method for the $N$ tetraalkylation of azamacrocycles. Beilstein J. Org. Chem. 2016, 12, 2457-2461 DOI: 10.3762/bjoc.12.239.

32. Yu, M.; Price, J. R.; Jensen, P.; Lovitt, C. J.; Shelper, T.; Duffy, S.; Windus, L. C.; Avery, V. M.; Rutledge, P. J.; Todd, M. H. Copper, Nickel, and Zinc Cyclam-Amino Acid and CyclamPeptide Complexes May Be Synthesized with "Click" Chemistry and Are Noncytotoxic. Inorg. Chem. 2011, 50 (24), 12823-12835 DOI: 10.1021/ic2020012.

33. Martin, L. Y.; DeHayes, L. J.; Zompa, L. J.; Busch, D. H. Relationship between metal-donor distance and ring size in macrocyclic complexes. J. Am. Chem. Soc. 1974, 96 (12), 4046-4048 DOI: $10.1021 / \mathrm{ja} 00819 \mathrm{a} 071$.

34. Bosnich, B.; Poon, C. K.; Tobe, M. L. Complexes of cobalt(III) with a cyclic tetradentate secondary amine. Inorg. Chem. 1965, 4 (8), 1102-8 DOI: 10.1021/ic50030a003.

35. Hoffert, W. A.; Shores, M. P. Crystallographic Coincidence of Two Bridging Species in a Dinuclear Co ${ }^{\mathrm{III}}$ Ethynylbenzene Complex. Acta Crystallogr. Sect. E 2011, 67 (7), m853-m854 DOI: doi:10.1107/S1600536811019969.

36. Sun, C.; Turlington, C. R.; Thomas, W. W.; Wade, J. H.; Stout, W. M.; Grisenti, D. L.; Forrest, W. P.; VanDerveer, D. G.; Wagenknecht, P. S. Synthesis of cis and trans Bis-Alkynyl 
Complexes of $\mathrm{Cr}(\mathrm{III})$ and $\mathrm{Rh}$ (III) Supported by a Tetradentate Macrocyclic Amine: a Spectroscopic Investigation of the M(III)-Alkynyl Interaction. Inorg. Chem. 2011, 50 (19), 9354-64 DOI: 10.1021/ic2009336.

37. Aurora, A.; Boiocchi, M.; Dacarro, G.; Foti, F.; Mangano, C.; Pallavicini, P.; Patroni, S.; Taglietti, A.; Zanoni, R. Single and Double $\mathrm{pH}-$ Driven $\mathrm{Cu}^{2+}$ Translocation with Molecular Rearrangement in Alkyne-Functionalized Polyamino Polyamido Ligands. Chem. Eur. J. 2006, 12 (21), 5535-5546 DOI: 10.1002/chem.200501235.

38. Addison, A. W.; Rao, T. N.; Reedijk, J.; van Rijn, J.; Verschoor, G. C. Synthesis, Structure, and Spectroscopic Properties of Copper(II) Compounds Containing Nitrogen-Sulphur Donor Ligands; the Crystal and Molecular Structure of Aqua[1,7-bis( $N$-methylbenzimidazol-2'-yl)2,6-dithiaheptane]copper(II) Perchlorate. J. Chem. Soc., Dalton Trans. 1984, (7), 1349-1356 DOI: $10.1039 / \mathrm{DT} 9840001349$.

39. Bakaj, M.; Zimmer, M. Conformational analysis of copper(II) 1,4,8,11tetraazacyclotetradecane macrocyclic systems. J. Mol. Struct. 1999, 508 (1), 59-72 DOI: 10.1016/S0022-2860(99)00032-0.

40. Corma, A.; Ruiz, V. R.; Leyva-Pérez, A.; Sabater, M. J. Regio- and Stereoselective Intermolecular Hydroalkoxylation of Alkynes Catalysed by Cationic Gold(I) Complexes. $A d v$. Synth. Catal. 2010, 352 (10), 1701-1710 DOI: 10.1002/adsc.201000094.

41. Alonso, F.; Beletskaya, I. P.; Yus, M. Transition-metal-catalyzed addition of heteroatomhydrogen bonds to alkynes. Chem. Rev. 2004, 104 (6), 3079-3160.

42. Castro, C.; Gaughan, E.; Owsley, D. Indoles, benzofurans, phthalides, and tolanes via copper (I) acetylides. J. Org. Chem. 1966, 31 (12), 4071-4078.

43. Kundu, N. G.; Chaudhuri, G.; Upadhyay, A. Palladium-Catalyzed Heteroannulation Leading to Heterocyclic Structures with Two Heteroatoms: A Highly Regio-and Stereoselective Synthesis of (Z)-4-Alkyl-2-alkyl (aryl) idene-3, 4-dihydro-2 H-1, 4-benzoxazines and (Z)-3-Alkyl (aryl) idene-4-tosyl-3, 4-dihydro-2 H-1, 4-benzoxazines. J. Org. Chem. 2001, 66 (1), 20-29.

44. Bertz, S. H.; Dabbagh, G.; Cotte, P. New Preparations of Ethyl 3,3-Diethoxypropionate and Ethoxycarbonylmalondialdehyde. Copper(I) Catalyzed Acetal Formation From a Conjugated Triple Bond. J. Org. Chem. 1982, 47 (11), 2216-2217.

45. Lee, J. Y.; Kang, S.-G.; Kwak, C.-H. Reaction of Primary Amines with N-Ethynyl Pendant Arms Attached to Macrocyclic Nickel(II) and Copper(II) Complexes: Formation of the Complexes with Pendant Imine Group(s). Inorg. Chim. Acta 2015, 430, 61-65 DOI: 10.1016/j.ica.2015.02.028. 
46. Trinchillo, M.; Belanzoni, P.; Belpassi, L.; Biasiolo, L.; Busico, V.; D’Amora, A.; D’Amore, L.; Del Zotto, A.; Tarantelli, F.; Tuzi, A.; Zuccaccia, D. Extensive Experimental and Computational Study of Counterion Effect in the Reaction Mechanism of NHC-Gold(I)Catalyzed Alkoxylation of Alkynes. Organometallics 2016, 35 (5), 641-654 DOI: 10.1021/acs.organomet.5b00925.

47. Pouy, M. J.; Delp, S. A.; Uddin, J.; Ramdeen, V. M.; Cochrane, N. A.; Fortman, G. C.; Gunnoe, T. B.; Cundari, T. R.; Sabat, M.; Myers, W. H. Intramolecular Hydroalkoxylation and Hydroamination of Alkynes Catalyzed by $\mathrm{Cu}(\mathrm{I})$ Complexes Supported by N-Heterocyclic Carbene Ligands. ACS Catalysis 2012, 2 (10), 2182-2193 DOI: 10.1021/cs300544w.

48. Sornosa Ten, A.; Humbert, N.; Verdejo, B.; Llinares, J. M.; Elhabiri, M.; Jezierska, J.; Soriano, C.; Kozlowski, H.; Albrecht-Gary, A.-M.; García-España, E. $\mathrm{Cu}^{2+}$ Coordination Properties of a 2-Pyridine Heptaamine Tripod: Characterization and Binding Mechanism. Inorg. Chem. 2009, 48 (18), 8985-8997 DOI: 10.1021/ic9010955.

49. Barsoum, D. N.; Brassard, C. J.; Deeb, J. H. A.; Okashah, N.; Sreenath, K.; Simmons, J. T.; Zhu, L. Synthesis of 5-Iodo-1,2,3-triazoles from Organic Azides and Terminal Alkynes-: Ligand Acceleration Effect, Substrate Scope, and Mechanistic Insights. Synthesis 2013, 45 (17), 2372-2386 DOI: 10.1055/s-0033-1339312.

50. Greco, N. J.; Hysell, M.; Goldenberg, J. R.; Rheingold, A. L.; Tor, Y. Alkyne-containing chelating ligands: synthesis, properties and metal coordination of 1,2-di(quinolin-8-yl)ethyne. Dalton Trans. 2006, (19), 2288-2290 DOI: 10.1039/B603983A.

51. Lang, H.; Köhler, K.; Blau, S. ๆ2-Alkyne Copper(I) and Silver(I) Compounds; from Polymeric [MIR] $\eta$ to Monomeric [MIR] units (M-Cu, Ag). Coord. Chem. Rev. 1995, 143, 113-168 DOI: 10.1016/0010-8545(94)07001-Z.

52. Baker, M. V.; Brown, D. H.; Skelton, B. W.; White, A. H. An Investigation into AlkenylFunctionalized 1,4,7-Triazacyclononanes: Synthesis, Metal Complexation, and Attempted Olefin Metathesis. Aust. J. Chem. 2002, 55 (10), 655-660 DOI: 10.1071/CH02063.

53. Kunze, A.; Gleiter, R.; Rominger, F. 1,8-Diazabicyclo[6.6.6]eicosa-4,11,17-triyne: a flexible cage for protons, copper(I) and silver(I). Chem. Commun. 1999, (2), 171-172 DOI: 10.1039/A808068B.

54. Ren, T. Sustainable Metal Alkynyl Chemistry: $3 \mathrm{~d}$ Metals and Polyaza Macrocyclic Ligands. Chem. Commun. 2016, 52 (16), 3271-3279 DOI: 10.1039/C5CC09365A.

55. Nishijo, J.; Enomoto, M. A Series of Weak Ferromagnets Based on a Chromium-AcetylideTTF Type Complex: Correlation of the Structures and Magnetic Properties and Origin of the Weak Ferromagnetism. Inorg. Chem. 2013, 52 (22), 13263-13268 DOI: 10.1021/ic402217c. 
56. Xu, H.-B.; Chao, H.-Y. Dinuclear Neodymium(III) Complex of Cationic $\left\{12[\text { ane }] \mathrm{HN}_{4}\left(\mathrm{CH}_{2} \mathrm{C} \equiv \mathrm{CH}\right)_{4}\right\}^{+}$With Sensitized Near-Infrared Luminescence by Ion-Association Sensitizer. Inorg. Chem. Commun. 2007, 10 (10), 1129-1131 DOI:

10.1016/j.inoche.2007.06.015.

57. Milne, M.; Chicas, K.; Li, A.; Bartha, R.; Hudson, R. H. E. ParaCEST MRI Contrast Agents Capable of Derivatization via "Click" Chemistry. Org. Biomol. Chem. 2012, 10 (2), 287-292 DOI: $10.1039 / \mathrm{C} 1 \mathrm{OB} 06162 \mathrm{C}$.

58. Ellis, D.; Farrugia, L. J.; Peacock, R. D. N,N',N"-1,4,7-Triazacyclononane With Pendant Alkyne Arms: Crystal Structures of $\left[\mathrm{CuL}_{2}{ }^{\prime}\right]\left[\mathrm{PF}_{6}\right]_{2},\left[\mathrm{NiL}_{2}{ }^{\prime}\right]\left[\mathrm{ClO}_{4}\right]_{2}$ and $\mathrm{CuL}^{\prime \prime} \mathrm{Cl}_{2}\left(\mathrm{~L}^{\prime}=\mathrm{N}-(4-\mathrm{But}-\right.$ 2-yne)-1,4,7-triazacyclononane, L"=N-(5-Pent-2-yne)-1,4,7-triazacyclononane). Polyhedron 1999, 18 (8-9), 1229-1234 DOI: 10.1016/S0277-5387(98)00420-3.

59. Seebald, L. M.; DeMott, C. M.; Ranganathan, S.; Asare-Okai, P. N.; Glazunova, A.; Chen, A.; Shekhtman, A.; Royzen, M. Cobalt-Based Paramagnetic Probe to Study RNA-Protein Interactions by NMR. J. Inorg. Biochem. 2017, 170, 202-208 DOI:

10.1016/j.jinorgbio.2017.02.024.

60. Caumes, C.; Fernandes, C.; Roy, O.; Hjelmgaard, T.; Wenger, E.; Didierjean, C.; Taillefumier,

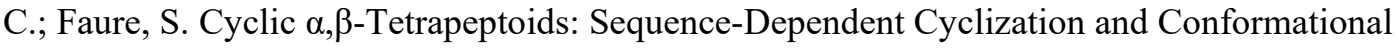
Preference. Org. Lett. 2013, 15 (14), 3626-3629 DOI: 10.1021/o1401478j.

61. Osseili, H.; Truong, K.-N.; Spaniol, T. P.; Maron, L.; Englert, U.; Okuda, J. Titanium Carbene Complexes Stabilized by Alkali Metal Amides. Angew. Chem. Int. Ed. 2019, 58 (6), 1833 1837 DOI: $10.1002 /$ anie.201812579.

62. Sheldrick, G. Crystal structure refinement with SHELXL. Acta Crystallogr. Sect. C 2015, 71 (1), 3-8 DOI: 10.1107/S2053229614024218.

63. Farrugia, L. WinGX and ORTEP for Windows: an Update. J. Appl. Crystallogr. 2012, 45 (4), 849-854 DOI: 10.1107/S0021889812029111.

64. Hubschle, C. B.; Sheldrick, G. M.; Dittrich, B. ShelXle: a Qt graphical user interface for SHELXL. J. Appl. Crystallogr. 2011, 44 (6), 1281-1284 DOI: 10.1107/S0021889811043202.

65. Dolomanov, O. V.; Bourhis, L. J.; Gildea, R. J.; Howard, J. A. K.; Puschmann, H. OLEX2: a complete structure solution, refinement and analysis program. J. Appl. Crystallogr. 2009, 42 (2), 339-341 DOI: 10.1107/S0021889808042726. 


\section{For Table of Contents Only}

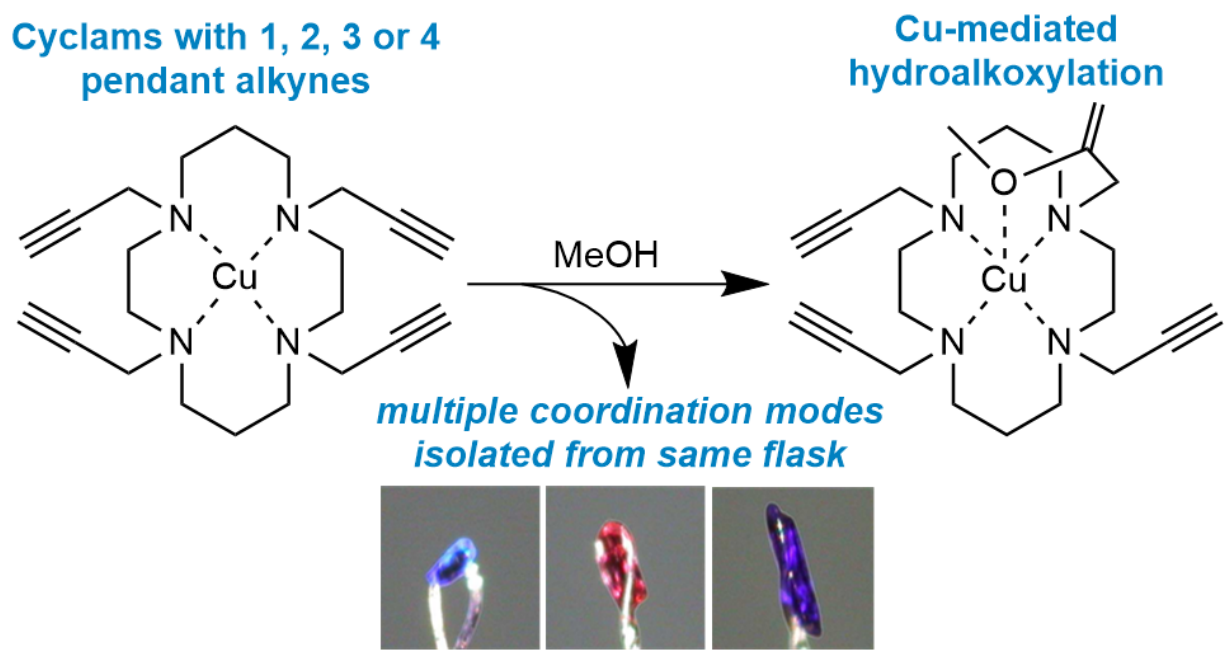

Synopsis: Cyclam ligands with pendant alkynes have burgeoning potential in the construction of diversely functionalised macrocyclic compounds via copper-catalysed azide-alkyne 'click' reactions. Yet the chemistry of alkyne-functionalised azamacrocycles remains relative unexplored. Cyclam ligands with 1, 2, 3 or 4 pendant alkynes are described, with crystallographic and spectroscopic experiments to characterise their copper(II) complexes. An unexpected hydroalkoxylation reaction is observed in the crystalline copper(II) complex of tetra- $N$-propargyl cyclam, affording an enol ether product. 